ENVIRONMENTAL RESTORATION PROGRAM

\section{Sampling Results, DNAPL Monitoring Well GW-730, Oak Ridge Y-12 Plant, Oak Ridge, Tennessee, First and Second Quarter, FY 1995}

\author{
FECEP:

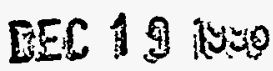 \\ (O) STI.
}

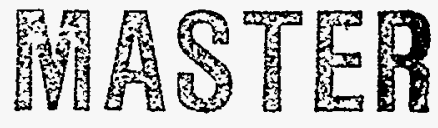

This document has been approved for release to the public by the Y-12 Plant Technical

Information Officer. Date: $11 / 30 / 95$

DISTRIBUTION OF THIS DOCUMENT IS UNLIMITED

ENERGY SYSTEMS 


\section{Oak Ridge Institute for Science and Education (ORISE)}

contributed to the preparation of this document and should not be considered an eligible contractor for its review.

This report has been reproduced directly from the best available copy.

Available to DOE and DOE contractors from the Office of Scientific and Technical Information, P.O. Box 62, Oak Ridge, TN 37831; prices available from 423-576-8401 (fax 423-576-2865).

Available to the public from the National Technical Information Service, U.S. Department of Commerce, 5285 Port Royal Rd., Springfield, VA 22161. 
Energy Systems Environmental Restoration Program

Sampling Results, DNAPL

Monitoring Well GW-730, Oak Ridge Y-12 Plant, Oak Ridge, Tennessee, First and Second Quarter, FY 1995

Date Issued-May 1996

Prepared for the

U.S. Department of Energy

Office of Environmental Management

under budget and reporting code EW 20

Environmental Management Activities at the

OAK RIDGE Y-12 PLANT

Oak Ridge, Tennessee 37831-8169

managed by

LOCKHEED MARTIN ENERGY SYSTEMS, INC.

for the

U.S. DEPARTMENT OF ENERGY

under contract DE-AC05-84OR21400 


\section{Author Affiliations}

R. B. Dreier is a member of the Environmental Sciences Division of Oak Ridge National Laboratory, Lockheed Martin Energy Research, Corp., Oak Ridge, Tennessee. A. J. Caldanaro is a participant in the Postgraduate Research Training Program administered by the Oak Ridge Institute for Science and Education, Oak Ridge, Tennessee. 


\section{DISCLAIMER}

Portions of this document may be illegible in electronic image products. Images are produced from the best available original document. 
May 1, 1996

Distribution

Dear Associates:

Transmittal of Sampling Results, DNAPL Monitoring Well GW-730, First and Second Quarter FY 1995, Y/ER-203

Enclosed you will find a copy of Sampling Results, DNAPL Monitoring Well GW-730, First and Second Quarter, FY 1995, Y/ER-203. This report has been developed by the Environmental Restoration Program for your information and use. The purpose of the document is to provide initial groundwater sampling results from multiport wells constructed around the Y-12 Burial Grounds. These wells were constructed in response to discovery of free phase DNAPL at the Burial Grounds. Results in this report provide contaminate monitoring information and, where appropriate, information for groundwater reference concentrations.

If you have any questions or comments regarding this document please contact RaNaye Dreier at (413) 574-7422.

Sincerely,

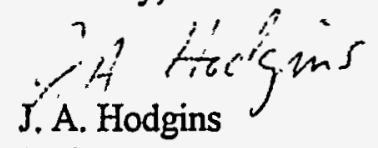

Project Manager

cc w/encl:

G. W. Bodenstein, DOE-ORO

M. Travaglini, DOE-ORO 
...

 


\section{PREFACE}

This document, Sampling Results, DNAPL Monitoring Well GW-730, First and Second Quarter FY 1995, was performed under Work Breakdown Structure 1.4.12.1.1.02 (Activity Data Sheet 2312, "Bear Creek Valley"). This document provides the Environmental Restoration Program (ER) with groundwater concentrations for nonradionuclides in the vicinity of the Oak Ridge Y-12 Plant Burial Grounds. This data can be used to determine reference concentrations for intermediate and deep groundwater systems.

\section{DISCLAIMER}

This report was prepared as an account of work sponsored by an agency of the United States Government. Neither the United States Government nor any agency thereof, nor any of their employees, makes any warranty, express or implied, or assumes any legal liability or responsibility for the accuracy, completeness, or usefulness of any information, apparatus, product, or process disclosed, or represents that its use would not infringe privately owned rights. Reference herein to any specific commercial product, process, or service by trade name, trademark, manufacturer, or otherwise does not necessarily constitute or imply its endorsement, recommendation, or favoring by the United States Government or any agency thereof. The views and opinions of authors expressed herein do not necessarily state or reflect those of the United States Government or any agency thereof. 



\section{CONTENTS}

\section{$\underline{\text { Page }}$}

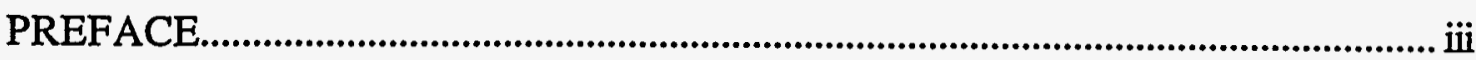

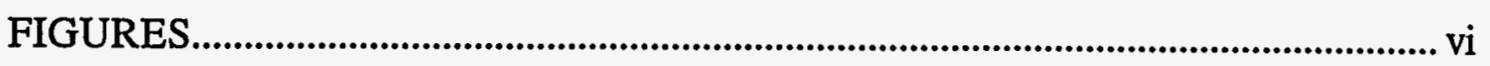

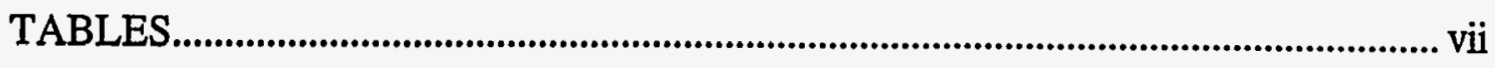

ACKNOWLEDGEMENTS............................................................................ viii

EXECUTIVE SUMMARY ...............................................................................

LIST OF ACRONYMS AND ABBREVIATIONS ...............................................

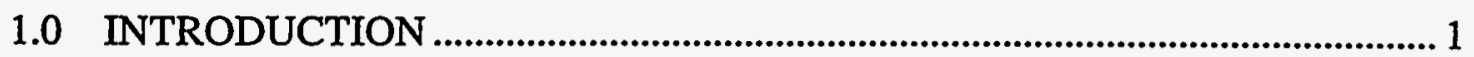

1.1 BACKGROUND AND PURPOSE.................................................... 1

1.2 BOREHOLE INFORMATION ............................................................ 2

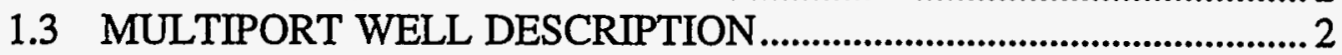

1.4 GW-730 SAMPLING ZONES .......................................................... 7

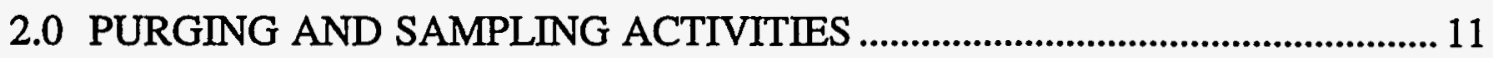

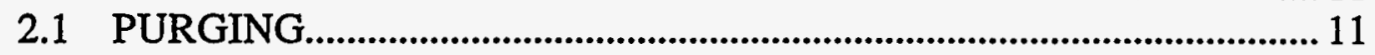

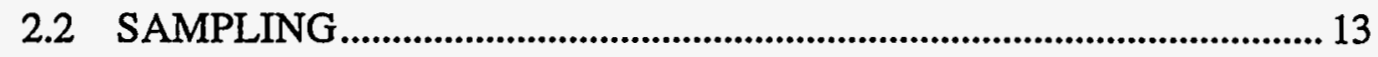

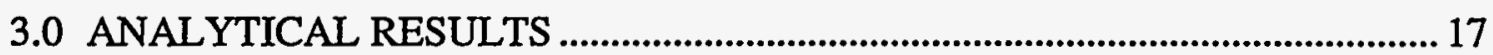

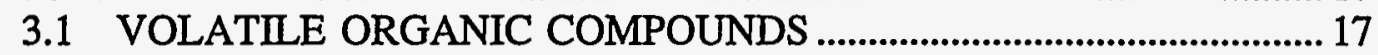

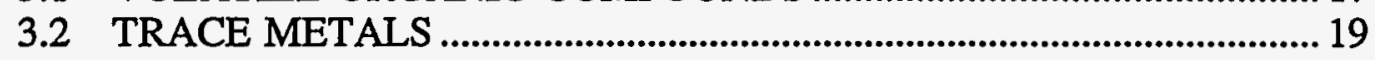

3.3 MAJOR ELEMENT WATER CHEMISTRY ..................................... 20

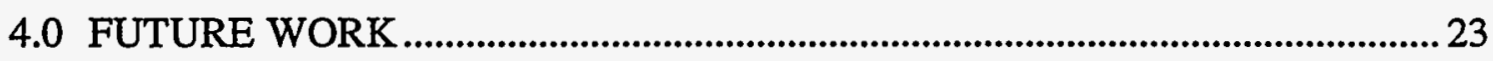

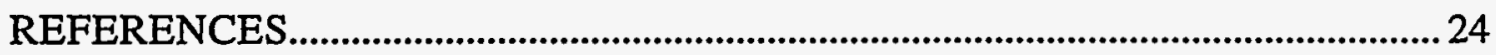

APPENDIX A. TRIP BLANK VOC ANALYTICAL RESULTS ............................ 25

APPENDIX B. LABORATORY BLANK VOC ANALYTICAL RESULTS........... 27

APPENDIX C. VOC ANALYTICAL RESULTS ................................................ 29

APPENDIX D. TRACE METAL ANALYTICAL RESULTS .............................. 34

APPENDIX E. MAJOR ANIONS AND CATIONS AND FIELD

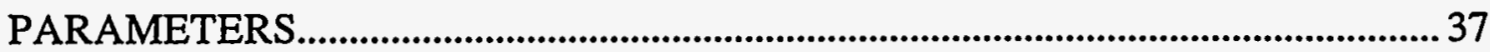

APPENDIX F. CHARGE BALANCE CALCULATIONS.................................... 40 


\section{FIGURES}

Figure

\section{Page}

1 Y-12 Burial Grounds location map.................................................................... 3

2 Generalized multiport well design........................................................................ 6

$3 \quad$ Multiport sampling zones for GW-730 ............................................................... 10

$4 \quad$ Plot of strontium vs. calcium concentrations from GW-730 ................................. 21

$5 \quad$ Piper Diagram of GW-730 Water Chemistry........................................................ 22 


\section{TABLES}

Table

1 GW-730 construction and well design information........................................... 4

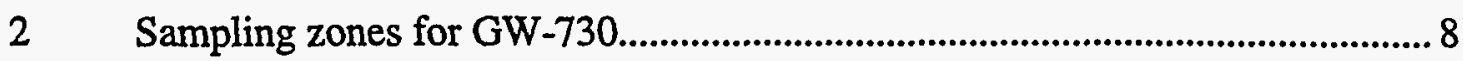

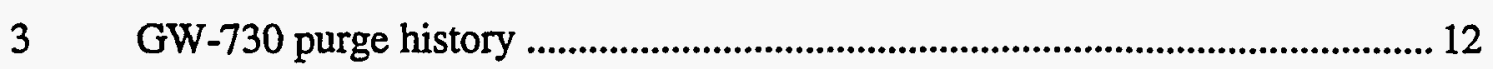

$4 \quad$ Sampling and analysis plan............................................................................... 14

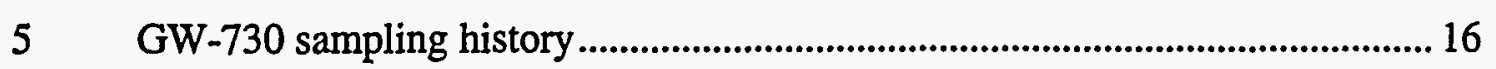

6 GW-730 "detects" from VOC analytical results.................................................. 18 


\section{ACKNOWLEDGMENTS}

This report could not have been completed without the help and cooperation from several people. Elizabeth Owens, with help as needed from Kirk Hyder, Jeff Williams and Anthony Garland, took care that all the field work was accomplished efficiently and properly. Y-12 ER organization through John Vanderlan, Helen King and Judy Hodgins provided program direction and financial support.

The authors also wish to thank C. T. Rightmire and D. B. Watson for their constructive review of the report. 


\section{EXECUTIVE SUMMARY}

In January 1990, dense, non aqueous phase liquids (DNAPLs) were discovered at a depth of approximately $274 \mathrm{ft}$. below ground surface along the southern border of the Y-12 Plant Burial Grounds. Immediately after the discovery, an investigation was conducted to assess the occurrence of DNAPL at the site and to make recommendations for further action. Results of the preliminary DNAPL investigation are presented in detail in Haase and King (1990a), and a work plan for assessment and characterization of the DNAPL is presented in Haase and King (1990b). A major task in the work plan calls for the construction and installation of five multiport wells. This report summarizes purging and sampling activities for one of these multiport wells, GW-730, and presents analytical results for GW-730.

To date, each of the eleven sampling zones in GW-730 has been sampled for VOCs, metals and anions. Based on the presence of very low levels of benzene at and below the base of the middle Nolichucky Shale, it is recommended that VOC monitoring of GW-730 be continued. Additional data is required in order to statistically confirm the presence or absence of VOCs through the use of "J" qualifiers. Zones 7 and 11 will be resampled in order to confirm or disprove the presence of nitrate in the deeper portions of the borehole. Purging activities will continue for zones $2,7,11,15$, and 18 to be followed by a second round of sampling. A comparison of the two sets of sampling results will be used to determine the need for a third round of purging. Any additional sampling from zones at the top of the well will be conducted without further purging, unless there is corroborative evidence that the water sample is not representative of the formation. There is a concern that excessive or unnecessary purging of fractured units with low storativity, such as those in GW-730, will mobilize and extend the contaminant plume.

Ongoing and future tasks are directed toward collecting data that will provide information about: (1) the presence or absence of DNAPL or dissolved phase DNAPL and (2) the nature of the groundwater system so that the potential mobility of the dissolved phase plume can be evaluated. With this information we will be prepared to address concerns about the current extent of the contamination, the potential for continued spread of the contamination, and the need, if any, for implementing a remediation strategy. 


\section{LIST OF ACRONYMS AND ABBREVIATIONS}

cps counts per second

DNAPL Dense Non Aqueous Phase Liquid

GC/MS Gas Chromatography / Mass Spectroscopy

ICP Inductively Coupled Plasma (spectroscopy)

IC Ion Chromatography

MCL Maximum Contaminant level

$\mathrm{mg} / \mathrm{L} \quad$ milligrams per liter

MP Multiport

ND Not Detected

OD Outer Diameter

psi pounds per square inch

PCE Tetrachloroethene

TCE Trichloroethene

TD Total Depth

TDS Total Dissolved Solids

VOC Volatile Organic Compounds

$\mathrm{mg} / \mathrm{L} \quad$ micrograms per liter 


\subsection{INTRODUCTION}

\subsection{BACKGROUND AND PURPOSE}

In January 1990, dense, non aqueous phase liquids (DNAPLs) were discovered at a depth of approximately $274 \mathrm{ft}$. below ground surface along the southern border of the Y-12 Plant Burial Grounds. Immediately after the discovery, an investigation was conducted to assess the occurrence of DNAPL at the site and to male recommendations for further action. To date, free-phase DNAPL contamination has been encountered in GW-625 (the discovery well), and is suspected to occur in GW-628 and GW-629 (Fig. 1) (Haase and King, 1990a). In addition, groundwater from GW-117 (Fig. 1) shows levels of volatile organic compounds suggestive of a dissolved contaminant plume. Results of the preliminary DNAPL investigation are presented in detail in Haase and King (1990a), and a work plan for assessment and characterization of the DNAPL is presented in Haase and King (1990b). A major task in the work plan calls for the construction and installation of five multiport wells. These wells (GW-726, GW-727, GW-729, GW-730, GW-730 and GW790) were constructed and instrumented with multiport components from August, 1991 to April, 1993 (Dreier and Caldanaro, 1994). Subsequently, purging and sampling activities were started in each well. This report summarizes purging and sampling activities for GW-730 and presents analytical results for GW-730.

The purpose of the multiport wells is two-fold and addresses specific recommendations made by an independent consultant and previous work (Keuper 1990; Haase and King 1990b):

1) Define the deep and intermediate groundwater flow system within the Bear Creek Burial Ground and contiguous areas. Place special emphasis on defining and characterizing major conductive zones through which most of the groundwater flow may be occurring or through which DNAPL migration may have occurred.

2) Track the dissolved plume from outside inward. With an understanding of the groundwater flow system, determine a nondetect envelope within which all DNAPL and dissolved DNAPL contamination exists. As such, the wells are intended to serve as an early warning system for dissolved plume migration. 
If future technological development provides a feasible method to remove DNAPLs, then data from the multiport wells will provide general knowledge of the DNAPL location. Additionally, the information developed will be necessary to evaluate the effectiveness of the remediation technology (Haase and King, 1990b).

\subsection{BOREHOLE INFORMATION}

The locations of the five muitipoti wells (GW-726, GW-727, GW-790, GW-729 and GW-730) are shown in Fig. 1. The rationale for well placement is given in Haase and King (1990b) and Dreier and Caldanaro (1994). Well GW-730 is located down dip from the discovery of free-phase DNAPL and downdip from localities where secondary groundwater contaminant plumes associated with DNAPL accumulations have been intercepted by other groundwater monitoring wells. Construction logs for GW-730 are presented in Science Applications International Corporation report, 1993, and the reader is referred to that report for a detailed construction history of the well. Condensed well construction information is presented in Table 1.

\subsection{MULTIPORT WELL DESCRIPTION}

The DNAPL investigation multiport wells use components designed by Westbay Instruments Inc. This system isolates zones of interest from each other by a series of packers fitted about a 1.5 in. diameter PVC (MP) casing (Fig. 2) that acts as an inner standpipe. Within specified sampling zones, fluid pressure data and water samples are collected using specialized probes that are lowered down the inner standpipe to the zones of interest. The probes access the zone through a measurement port coupling in the MP casing. Each sampling zone also contain a pumping port, which is used exclusively for purging. Because the packers isolate each sampling zone from the atmosphere, it is not necessary to purge before each sampling event. Purging is only needed to remove fluids that may have been introduced into the zone during drilling and installation operations.

The sampling zones are isolated from each other by one to two additional zones, called QA zones, containing measurement ports, from which only fluid pressure data are collected (Fig. 2). The zones provide added assurance that the sampling zones are isolated from each other. Although, it is possible to obtain water samples from these zones, the zones do not contain pumping ports and it is not possible to purge these intervals. Thus these zones have limited value for characterizing water chemistry. 


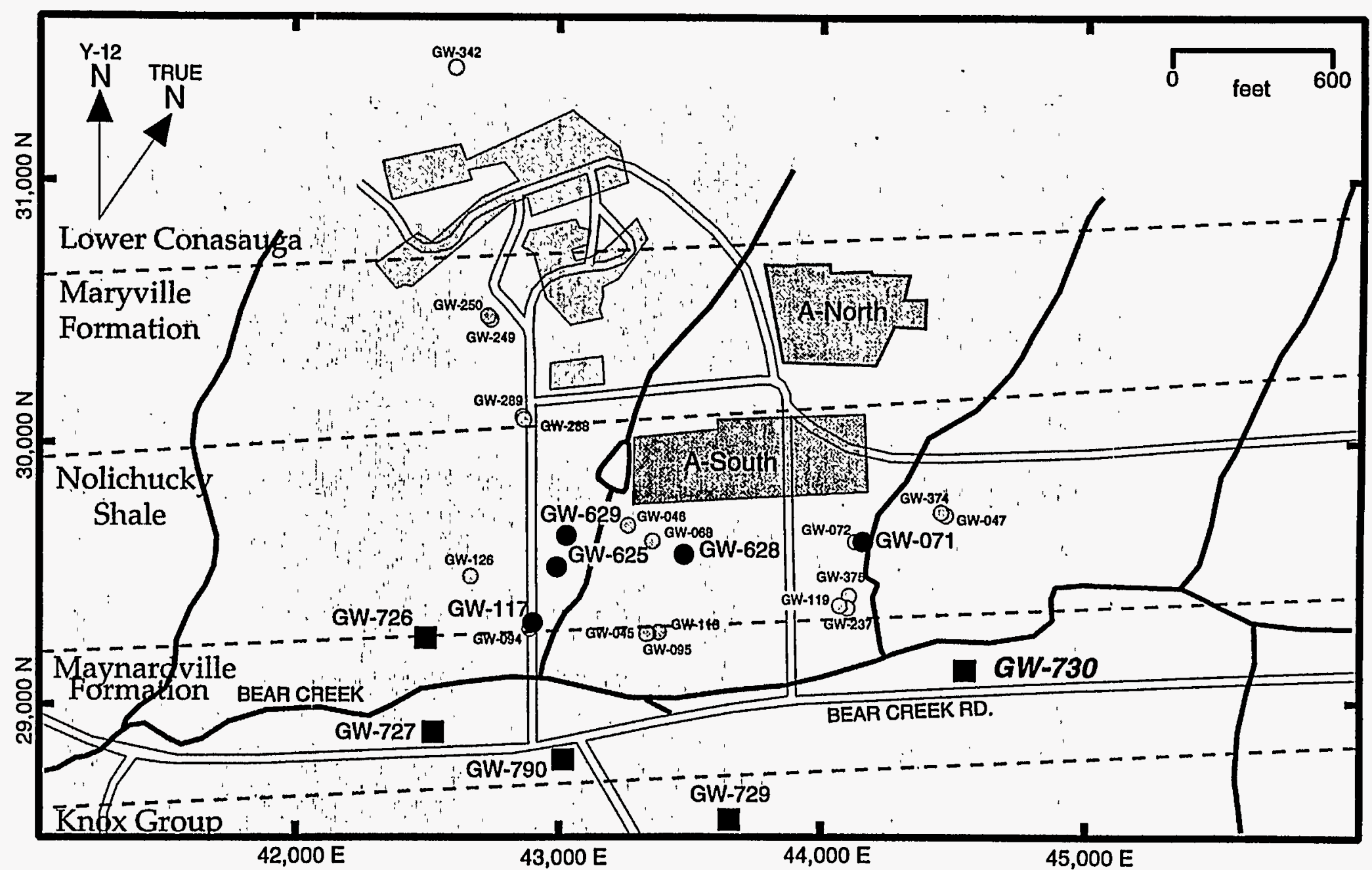

Fig. 1. Y-12 Burial Grounds location map. Dark circles are wells with known DNAPL accumulation or are wells that intercept secondary groundwater contaminant plumes. Black squares are the five multiport DNAPL investigation wells. GW-730 is highlighted. Estimated locations of geologic contacts are shown. 
Table 1. GW-730 construction and well design information BOREHOLE CONSTRUCTION \begin{tabular}{|l|r}
\hline Surface Casing (ft bgs) & 420.3 \\
\hline
\end{tabular} \begin{tabular}{|l|r|} 
Total Depth (ft bgs) & 1424.8 \\
\hline
\end{tabular}

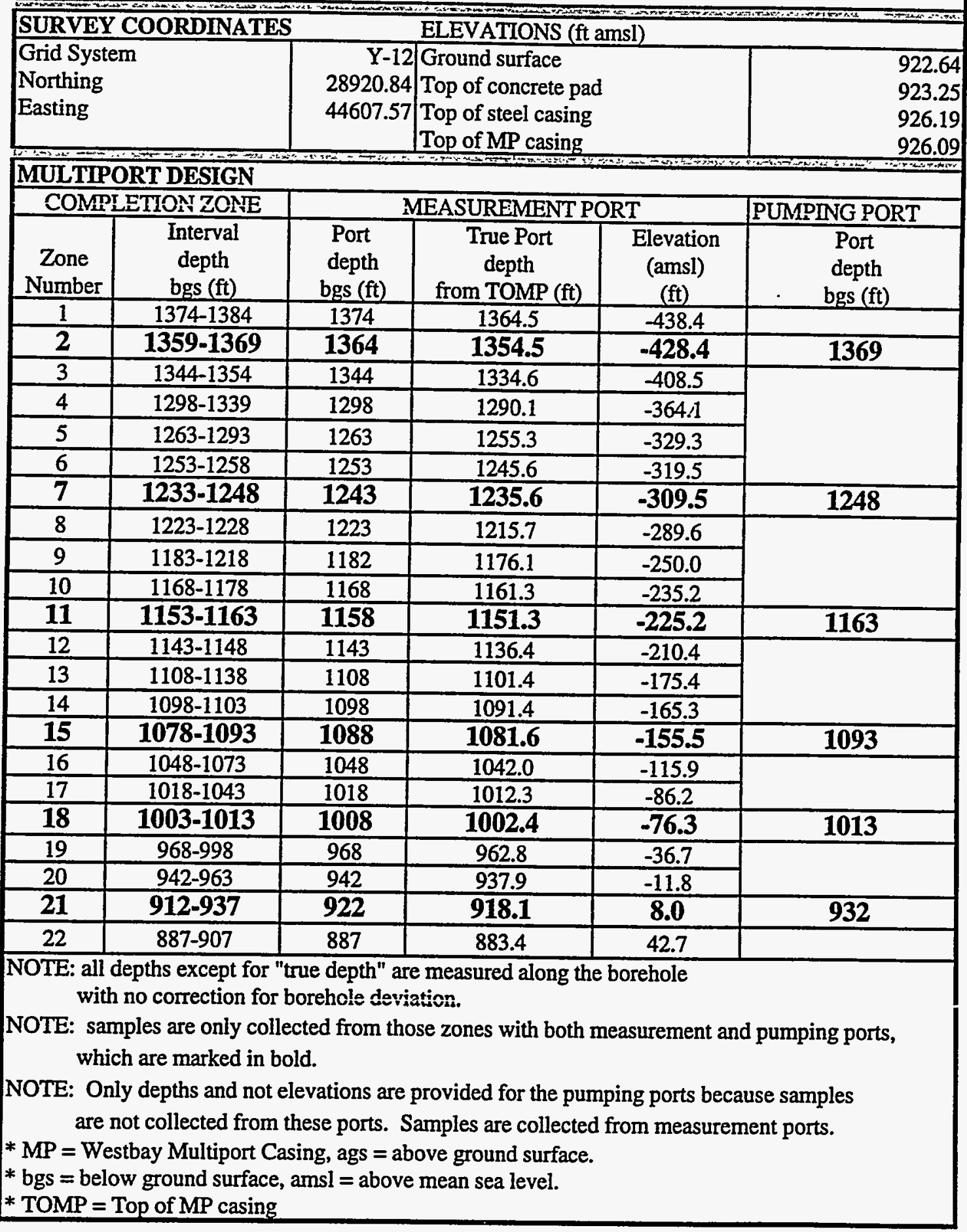


Table 1. cont.

\begin{tabular}{|c|c|c|c|c|c|}
\hline \multicolumn{6}{|c|}{ MULTIPORT DESIGN } \\
\hline \multicolumn{2}{|c|}{ COMPLETION ZONE } & \multicolumn{3}{|c|}{ MEASUREMENT PORT } & \multirow{2}{*}{$\begin{array}{c}\text { PUMPING PORT } \\
\text { Port } \\
\text { depth } \\
\text { bgs (ft) }\end{array}$} \\
\hline $\begin{array}{c}\text { Zone } \\
\text { Number }\end{array}$ & $\begin{array}{c}\text { Interval } \\
\text { depth } \\
\text { bgs (ft) } \\
\end{array}$ & $\begin{array}{c}\text { Port } \\
\text { depth } \\
\text { bgs }(f t)\end{array}$ & $\begin{array}{c}\text { True Port } \\
\text { depth } \\
\text { from TOMP (ft) }\end{array}$ & $\begin{array}{l}\text { Elevation } \\
\text { (amsl) } \\
\text { (ft) }\end{array}$ & \\
\hline 23 & $862-882$ & 862 & 858.5 & 67.6 & \\
\hline 24 & $847-587$ & 847 & 843.7 & 82.4 & \\
\hline 25 & 832-842 & 837 & 833.7 & 92.3 & 842 \\
\hline 26 & $792-827$ & 792 & 789.1 & 137.0 & \\
\hline 27 & $767-787$ & 767 & 764.2 & 161.9 & \\
\hline 28 & $747-762$ & 757 & 754.4 & 171.7 & 762 \\
\hline 29 & $732-742$ & 732 & 729.4 & 196.7 & \\
\hline 30 & $717-727$ & 722 & 719.6 & 206.5 & 727 \\
\hline 31 & $687-712$ & 687 & 684.7 & 241.4 & \\
\hline 32 & $657-682$ & 657 & 655.0 & 271.1 & \\
\hline 33 & $627-652$ & 627 & 625.2 & 300.9 & \\
\hline 34 & $597-622$ & 597 & 595.4 & 330.7 & \\
\hline 35 & $576-592$ & 586 & 585.2 & 340.9 & 592 \\
\hline 36 & $551-571$ & 551 & 550.6 & 375.5 & \\
\hline 37 & $526-546$ & 526 & 525.6 & 400.5 & \\
\hline 38 & $496-521$ & 496 & 495.7 & 430.4 & \\
\hline 39 & $471-491$ & 481 & 480.7 & 445.3 & 491 \\
\hline 40 & $436-466$ & 436 & 436.0 & 490.1 & \\
\hline 41 & $0-431$ & 421 & 420.8 & 505.2 & \\
\hline \multicolumn{6}{|c|}{$\begin{array}{l}\text { NOTE: all depths except for "true depth" are measured along the borehole } \\
\text { with no correction for borehole deviation. } \\
\text { NOTE: samples are only collected from those zones with both measuremer } \\
\text { which are marked in bold. } \\
\text { NOTE: Only depths and not elevations are provided for the pumping ports } \\
\text { are not collected from these ports. Samples are collected from meas }\end{array}$} \\
\hline
\end{tabular}




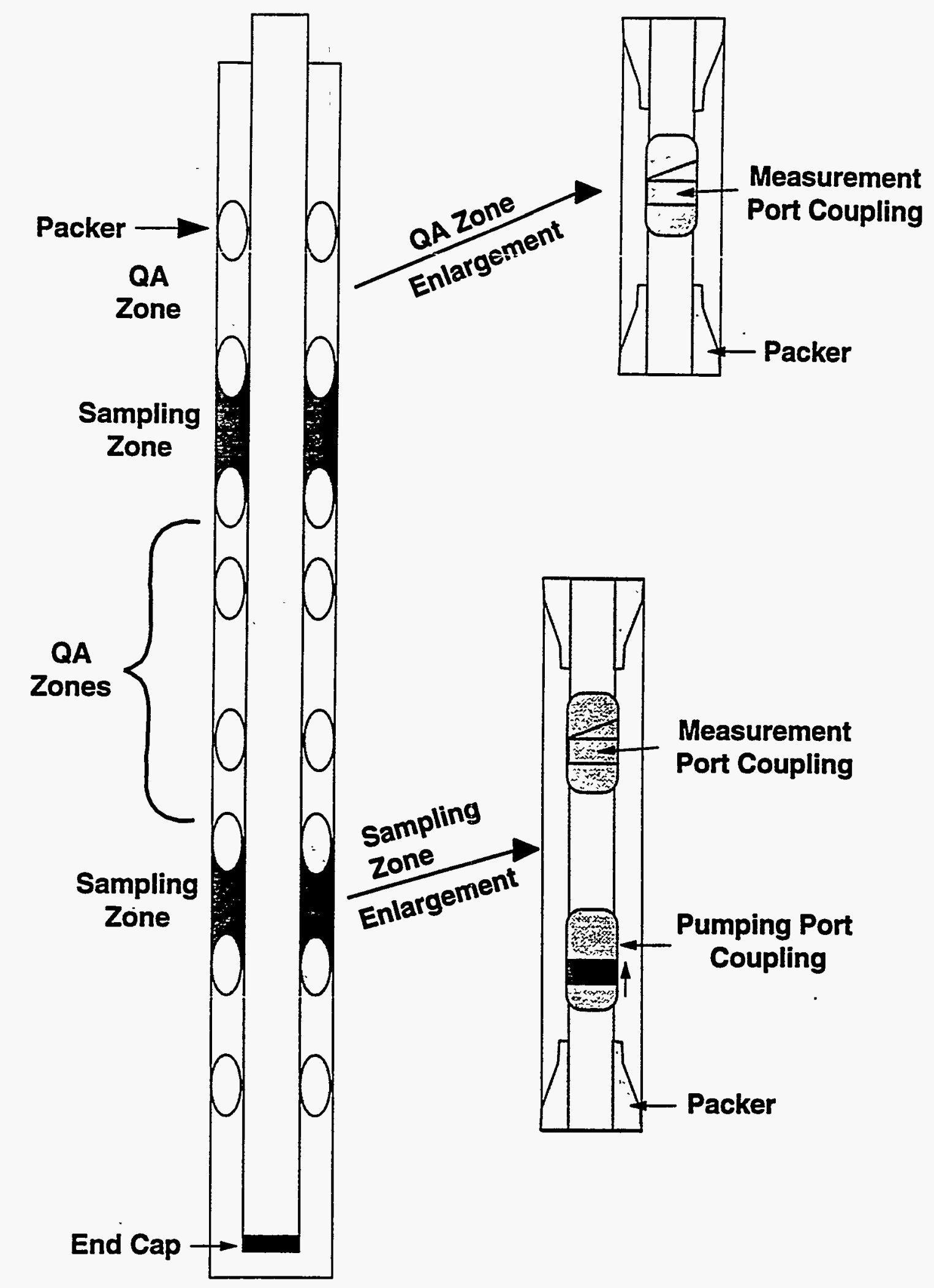

Figure 2. Generalized multiport well design. 


\subsection{GW-730 SAMPLING ZONES}

The multiport completion design for GW-730 is shown in Table 1. On the basis of core samples, geophysical logs and flowmeter results, 11 sampling zones, 10-to-25 ft. long, were selected from GW-730. The reader is referred to Dreier and Caldanaro (1994) for a more detailed description of the technical rationale and component design for each of the DNAPL investigation wells. Table 11 from Dreier and Caldanaro (1994) specifically lists criteria for choosing sampling zones and is repeated here as Table 2 for clarification. The installation history for GW-730 is documented in Westbay Instruments Inc. (1993).

The zones were chosen to sample at least one of the following features, in order of priority. (1) fluids from potential zones of DNAPL migration, (2) fluids from hydraulically conductive fractures or fracture zones, (3) potential changes in fluid chemistry with depth, (4) fluids that show water chemistry signatures associated with a particular rock type, (5) fluids that may show water chemistry correlations between wells, and (6) matrix fluids with long residence times. In general, criteria 3,4 and 5 can be achieved by having a relatively regular vertical distribution of sampling zones. The spacing between most zones is less than $100 \mathrm{ft}$, and spacing less than $80 \mathrm{ft}$ is common in potential DNAPL regions.

The stratigraphic positions of the eleven sampling zones in GW-730 are shown in Fig. 3. A zone of potential DNAPL migration, shown as a broad shaded portion, (Dreier and Caldanaro, 1994) was identified before the well was instrumented with Westbay components and is based on stratigraphic correlation with GW-625, GW-628, GW-629 and GW-117. This zone is the oolitic-rich limestone interval that defines the base of the middle Nolichucky Shale (Hatcher et.al, 1992) and is sampled by zone 28 and 30. In addition, GW-730 was drilled substantially deeper than the other Westbay-instrumented well in order to intercept the Maryville Formation, which underlies Burial Ground ANorth. Waste oils, coolants and spent solvents were disposed in Burial Ground A-North as well as Burial Ground A-South. This well, which of the 5 monitoring wells is located closest to the immediate down-dip direction from Burial Ground A-North (Fig. 1), will be used to monitor potential strata-bound DNAPL migration pathways from the northern burial ground. 
Table 2. Sampling zones for GW-730a

\begin{tabular}{|c|c|c|c|c|}
\hline $\begin{array}{l}\text { Multiport } \\
\text { Zone }^{b}\end{array}$ & $\begin{array}{l}\text { Depth } \\
(\text { ft. })^{c, d}\end{array}$ & $\begin{array}{l}\text { Samp. port } \\
\text { depth }(\mathrm{ft} .)^{c, d}\end{array}$ & Purpose & Logs/Core \\
\hline 39 & $\begin{array}{l}471-491 \\
(470-490)\end{array}$ & $\begin{array}{c}481 \\
(480)\end{array}$ & $\begin{array}{l}\text { Sample fracture at top of cored } \\
\text { interval }\end{array}$ & $\begin{array}{l}\text { core: Fractures } 478^{\prime}, 480^{\prime} \\
\text { logs: Long-short normal difference } 490^{\prime} \\
\text { stratigraphy: middle Nolichucky Shale }\end{array}$ \\
\hline 35 & $\begin{array}{l}576-592 \\
(575-590)\end{array}$ & $\begin{array}{l}586 \\
(585)\end{array}$ & $\begin{array}{l}\text { Sample fracture, vertical } \\
\text { distribution }\end{array}$ & $\begin{array}{l}\text { core: Fractures } 576^{\prime}, 577^{\prime}, 580^{\prime}, 583^{\prime}, 587^{\prime} \\
\text { logs: Large long-short normal difference; In zone of } \\
\text { high SP } \\
\text { stratigraphy: middle Nolichucky Shale }\end{array}$ \\
\hline 30 & $\begin{array}{l}717-727 \\
(715-725)\end{array}$ & $\begin{array}{l}722 \\
(720)\end{array}$ & $\begin{array}{l}\text { Sample fractures within potential } \\
\text { zone of DNAPL migration at base } \\
\text { of middle Nolichucky Shale. }\end{array}$ & $\begin{array}{l}\text { core: Fractures } 715^{\prime}, 717^{\prime}, 724^{\prime}, 726^{\prime} \\
\text { logs: Large long-short normal difference } 720^{\prime}, \text { small } \\
\text { temperature anomaly } \\
\text { stratigraphy: base of middle Nolichucky Shale }\end{array}$ \\
\hline 28 & $\begin{array}{l}747-762 \\
(745-760)\end{array}$ & $\begin{array}{l}757 \\
(755)\end{array}$ & $\begin{array}{l}\text { Sample fractures within potential } \\
\text { zone of DNAPL migration at base } \\
\text { of middle Nolichucky Shale. }\end{array}$ & $\begin{array}{l}\text { core: Fractures } 753.2^{\prime}, 753.8^{\prime}, 756^{\prime} \\
\text { logs: Minor SP change } 750^{\prime} \text {. Long-short normal } \\
\text { difference } 760^{\prime}, \text { small temperature anomaly } \\
\text { stratigraphy: base of middle Nolichucky Shale }\end{array}$ \\
\hline 25 & $\begin{array}{l}832-842 \\
(830-840)\end{array}$ & $\begin{array}{c}837 \\
(835)\end{array}$ & $\begin{array}{l}\text { Sample fracture below potential } \\
\text { DNAPL zone. }\end{array}$ & $\begin{array}{l}\text { core: Fractures } 832.1^{\prime}, 832.2^{\prime} \\
\text { logs: No fractures identified. } \\
\text { stratigraphy: lower Nolichucky Shale }\end{array}$ \\
\hline 21 & $\begin{array}{l}912-937 \\
(910-935)\end{array}$ & $\begin{array}{l}922 \\
(920)\end{array}$ & Sample fracture. & $\begin{array}{l}\text { Core: Fracture } 921.6^{\prime} \text {; fault } 920.2^{\prime} \\
\text { logs: Caliper } 912^{\prime}, 920^{\prime}, 929^{\prime}, \text { SP high (get change to } \\
\text { lower } 920^{\prime} \text { ), minor long-short normal difference, small } \\
\text { temperature anomaly. } \\
\text { stratigraphy: lower Nolichucky Shale }\end{array}$ \\
\hline 18 & $\begin{array}{l}1003- \\
1013 \\
(1000- \\
1010)\end{array}$ & $\begin{array}{l}1008 \\
(1005)\end{array}$ & $\begin{array}{l}\text { Sample stratigraphy of burial } \\
\text { Ground A-North, vertical } \\
\text { distribution. }\end{array}$ & $\begin{array}{l}\text { core: No fractures identified. } \\
\text { logs: Slightly high SP \& long-short normal difference } \\
\text { stratigraphy: Maryville Formation }\end{array}$ \\
\hline 15 & $\begin{array}{l}1078- \\
1093 \\
(1075- \\
1090)\end{array}$ & $\begin{array}{l}1087 \\
(1085)\end{array}$ & $\begin{array}{l}\text { Sample deformation zone and } \\
\text { fracture. Sample stratigraphy of } \\
\text { Burial Ground A-North. }\end{array}$ & $\begin{array}{l}\text { core: fault--fold zone 1076-1085', fracture } 1086^{\prime} \\
\text { logs: High SP \& long-short normal difference. } \\
\text { stratigraphy: Maryville Formation }\end{array}$ \\
\hline 11 & $\begin{array}{l}1153- \\
1163 \\
(1150- \\
1160)\end{array}$ & $\begin{array}{l}1158 \\
(1155)\end{array}$ & $\begin{array}{l}\text { Sample fractures in Maryville } \\
\text { Formation. }\end{array}$ & $\begin{array}{l}\text { core: fracture } 1159 \text { ' probably tight } \\
\text { logs: not available } \\
\text { stratigraphy: Maryville Formation }\end{array}$ \\
\hline
\end{tabular}


Table 2. (cont.)

\begin{tabular}{|c|c|c|l|l|}
\hline 7 & $\begin{array}{c}1233- \\
1248 \\
(1230-\end{array}$ & $\begin{array}{c}1243 \\
(1240)\end{array}$ & $\begin{array}{l}\text { Sample fractures in Maryville } \\
\text { Formation. }\end{array}$ & $\begin{array}{l}\text { core: fractures } 1234^{\prime}, 1245^{\prime} ; \text { fault 1244' } \\
\text { logs: not available } \\
\text { stratigraphy: Maryville Formation }\end{array}$ \\
\hline 2 & $\begin{array}{c}1359- \\
1379 \\
(1355- \\
1365)\end{array}$ & $\begin{array}{c}1364 \\
(1360)\end{array}$ & Sample well bottom (TD=1424') & $\begin{array}{l}\text { core: No fractures identified. } \\
\text { logs: not available } \\
\text { stratigraphy: Maryville Formation }\end{array}$ \\
\hline
\end{tabular}

arepeated vertbatim from Dreier and Caldanaro (1994), Table 11.

bMultiport zone number.

cDepth measured from ground surface, not corrected for borehole deviation

dParentheses denote planned diepth. Other number is correct downhole depth. 


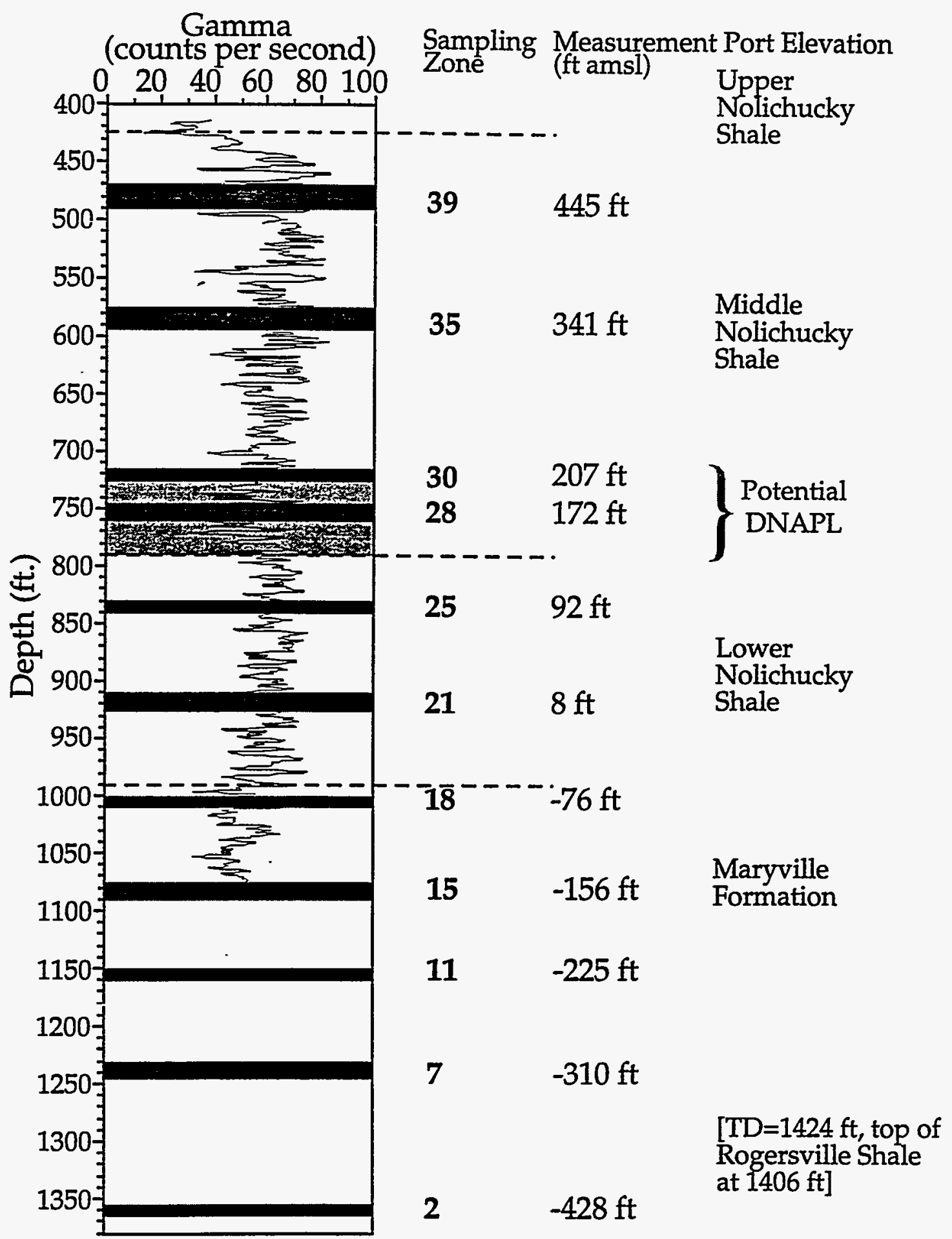

Figure 3. Multiport sampling zones for GW-730. The region marked Potential DNAPL is not meant to imply that DNAPL occurs in this interval at this location. Rather, this zone correlates to the same stratigraphic interval at shallower depths up dip where DNAPL was visually observed and where dissolved phase plumes were identified. 


\subsection{PURGING AND SAMPLING ACTIVITIES}

\subsection{PURGING}

Initial purging of the sample zones in GW-730 began in May of 1993, several months after hydraulic heads had stabilized from multiport installation, and continued though March of 1995 (Table 3). During purging, an appropriate volume of water is extracted from the inner standpipe so that the hydraulic head in the standpipe is lower than the hydraulic head in the sampling zone. This induces water to flow from the formation and annular space through the open purge port into the inner standpipe. Recommended purge volumes are calculated at three times the annular volume of the sampling zone (Table 3). The rate at which this volume is produced is a function of the rock permeability and can vary considerably. In particular, it was found that very low permeability zones could take several months or longer to produce the requisite volumes. Because of this, purging procedures were modified so that sampling activities could fit into a reasonable scheduling framework. At present, each zone is purged for one month or until the recommended volume of water is produced, whichever occurs first. The zone is then sampled. If the zone does not produce enough water during the first round of purging, purging is continued for another month, to be followed by a second round of sampling. Additional purging requirements will be determined on a case-by-case basis, but in general, the removal of one annular volume for very low permeability zones at the base of the borehole may be considered adequate in the future.

Of eleven sampling zones in GW-730, only three produced the requisite three annular volumes within a month of purging. These zones (zones 21, 25 and 35) are in the upper portion of the well and may indicate that permeability decreases with increasing depth. However note that purge times for zones 25 and 21 were approximately 2 and 6 months respectively. It is only the uppermost zones (zones 35 and 39) that appear to have the potential to purge in less that two weeks. Purge volumes for zones 28,30 and 39 are slightly under three annular volumes (Table 3 ) This is because a purge volume calculation provided by Westbay Instruments proved to over estimate produced water volumes, and this mistake was discovered after these zones had been purged. Of the remaining 5 zones at the base of the well, two produced at least one annular volume (zones 15 and 17). Zones 2,11 and 18 were open for approximately one month and did not produce one annular volume. However, they did produced aproximately 0.5 annular volume in one month. Therefore it is anticipated that with another round of month-long purging, this zone will be able to produce at least one annular volume. 
Table 3. GW-730 purge history

\begin{tabular}{|c|c|c|c|c|c|c|c|c|c|c|}
\hline Zone & $\begin{array}{c}\text { Packed-off } \\
\text { Sampling } \\
\text { Zone Height } \\
\text { (ft) }\end{array}$ & $\begin{array}{l}\text { Recom. } \\
\text { purge } \\
\text { volume } \\
\text { (gals)* }\end{array}$ & $\begin{array}{l}\text { 1st Purge } \\
\text { Date } \\
\text { Opened }\end{array}$ & $\begin{array}{l}\text { 1st Purge } \\
\text { Date } \\
\text { Closed }\end{array}$ & $\begin{array}{l}\text { Produced } \\
\text { purge vol. } \\
\text { (gals) }\end{array}$ & $\begin{array}{c}\text { 2nd Purge } \\
\text { Date } \\
\text { Opened }\end{array}$ & $\begin{array}{c}\text { 2nd Purge } \\
\text { Date } \\
\text { Closed }\end{array}$ & $\begin{array}{c}\text { Produced } \\
\text { purge vol. } \\
\text { (gals) }\end{array}$ & $\begin{array}{l}\text { Total } \\
\text { no. } \\
\text { annular } \\
\text { vols. }\end{array}$ & $\begin{array}{c}\text { Difference } \\
\text { of actual (-) } \\
\text { recom. } \\
\text { (gals) }\end{array}$ \\
\hline 2 & 11 & 14 & $1 / 31 / 95$ & $3 / 7 / 95$ & 1.9 & & & & 0.4 & -12 \\
\hline 7 & 16 & 20 & $12 / 29 / 94$ & $1 / 31 / 95$ & 11.5 & & & & 1.7 & -8.7 \\
\hline 11 & 11 & 14 & $9 / 21 / 93$ & $10 / 14 / 93$ & **na & $11 / 29 / 94$ & $12 / 29 / 94$ & 2.2 & 0.5 & -11.7 \\
\hline 15 & 16 & 20 & $9 / 2 / 93$ & $9 / 20 / 93$ & ${ }^{* *}$ na & $10 / 20 / 94$ & $11 / 29 / 94$ & 7.5 & $\overline{1.1}$ & -12.7 \\
\hline 18 & 11 & 14 & $8 / 23 / 93$ & $9 / 1 / 93$ & **na & $8 / 4 / 94$ & $10 / 20 / 94$ & 2.0 & $\overline{0.4}$ & -11.8 \\
\hline 21 & 26 & 33 & $8 / 3 / 93$ & $8 / 20 / 93$ & ${ }^{* *}$ na & $1 / 26 / 94$ & $8 / 4 / 94$ & 37.9 & 3.5 & 5.1 \\
\hline 25 & 11 & 14 & $7 / 29 / 93$ & $8 / 3 / 93$ & **na & $11 / 30 / 93$ & $1 / 25 / 94$ & 16.8 & 3.6 & 3.0 \\
\hline 28 & 16 & 20 & $7 / 23 / 93$ & $7 / 29 / 93$ & **na & $10 / 26 / 93$ & $11 / 30 / 93$ & 18.3 & 2.7 & -1.9 \\
\hline 30 & 11 & 14 & $7 / 12 / 93$ & $7 / 22 / 93$ & ${ }^{* *}$ na & $10 / 18 / 93$ & $10 / 22 / 93$ & 13.2 & 2.9 & -0.6 \\
\hline 35 & 16 & 20 & $5 / 18 / 93$ & $6 / 1 / 93^{* *}$ & 30.64 & & & & 4.6 & 10.5 \\
\hline 39 & 21 & 26 & $5 / 5 / 93$ & $5 / 11 / 93$ & 25.59 & & & & 2.9 & -0.9 \\
\hline $\begin{array}{l}\text { Recomm } \\
3.7 \text { " dian } \\
\text { "= } 0.42 \mathrm{~g} \\
\text { ** The p } \\
\text { purging }\end{array}$ & $\begin{array}{l}\text { fort for one a } \\
\text { rge port for } \\
\text { f zones } 11,1\end{array}$ & $\begin{array}{l}\text { and } 1.81 \\
\text { nular vo } \\
\text { one } 35 \text { is } \\
18,21 \text {, }\end{array}$ & $\begin{array}{l}\text { ATION: } \\
3 \text { annular va } \\
\text { ' OD MP ca } \\
\text { lume or } 1.2 \\
\text { partially op } \\
25,28 \text { and }\end{array}$ & $\begin{array}{l}\text { lumes } \\
\text { sing } \\
6 \mathrm{gal} / \mathrm{ft} \text { for } \\
\text { en from } 6 / 1 \\
30 \text { during th }\end{array}$ & $\begin{array}{l}\text { hree annula } \\
193 \text { to } 10 / 1 \\
\text { at period is }\end{array}$ & $\begin{array}{l}\text { Ir volumes" } \\
\text { 8/93. There } \\
\text { voided. }\end{array}$ & 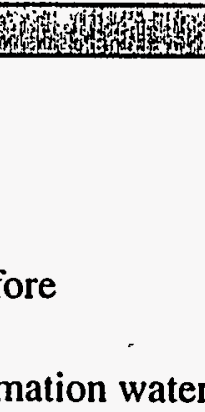 & 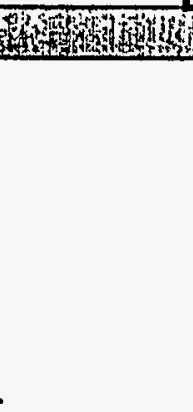 & 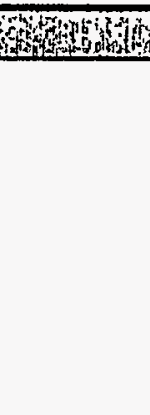 & 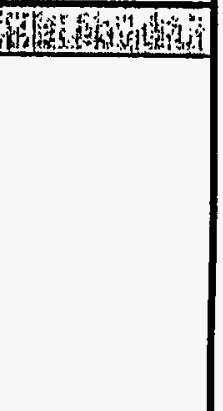 \\
\hline
\end{tabular}




\subsection{SAMPLING}

Samples are collected in two evacuated (under vacuum) stainless steel $250 \mathrm{ml}$ sample bottles that are attached in tandem and threaded to a sampling probe. The sample bottles are lowered to the desired zone and water is extracted through the measurement port valve. All equipment is designed specifically for and dedicated to Westbay type multiport wells. Additional information on Westbay-specific sampling procedures is in the Westbay Operation Manuals, which are available from the authors of this report.

The field sampling protocol is given in Table 4. Initially, each zone is sampled for anions, metals, VOCs and field parameters $(\mathrm{pH}$, specific conductance and temperature). The normal suite of anion analysis includes $\mathrm{Cl}, \mathrm{Fl}, \mathrm{NO}_{3}$, and $\mathrm{SO}_{4}$. If the specific conductance is greater than 2000 umho/cm, $\mathrm{Br}$ is added to the suite since its concentration may be above detection at elevated specific conductance levels. Additional sampling events are based on initial analytical results and are determined at the discretion of the project manager or project technical lead.

Using two sample bottles, a maximum sample volume of $500 \mathrm{ml}$ can be obtained each time bottles are lowered to a port (a sample run) (Table 4). In general, either two or three runs are needed to collect the required sample volume, depending on the desired analysis. Two different protocols are used based on the suspected permeability of the sampling zone. For high to moderate permeability zones, the first run is used to collect field parameters and to rinse the sample bottles with formation water. If both inorganic (major and trace elements) and organic constituents are being sampled, the second run is used for the major and trace inorganic water samples and the third run is used for the VOC sample. VOCs are collected last to maximize the number of sample bottle rinses with formation water.

As of February, 1995, several types of control samples are collected during sampling: (1) A trip blank sample is obtained each time a VOC sample is collected; (2) A field blank is prepared for $10 \%$ of the VOC sampling events; (3) A duplicate sample is collected for $10 \%$ of all sampling events. (4) An equipment rinsate, consisting of the final DI water rinse from the inside of the sample bottle, is collected for $10 \%$ of all sampling events. Zones 2, 7, 11 and 15 were sampled after February 1995, but these samples were not part of the $10 \%$ population used for duplicates or equipment rinsates. 
Table 4. Sampling and analysis plan.

High to Moderate Permeability

\begin{tabular}{|c|c|c|c|c|c|c|c|c|}
\hline $\begin{array}{r}\text { Sar } \\
\text { Run No. }\end{array}$ & $\begin{array}{l}\text { mple } \\
\text { Bottle No. }\end{array}$ & Parameter & $\begin{array}{c}\text { Container } \\
\text { Type }\end{array}$ & $\begin{array}{l}\text { Volume } \\
\text { (ml) }\end{array}$ & Filtered & Preservative & Procedure No. & $\begin{array}{l}\text { Analytical } \\
\text { Method }\end{array}$ \\
\hline 1 & 1 & $\mathrm{pH}$ & N/A & $<250$ & YES & N/A & EPA-150.1 & pH meter \\
\hline 1 & 1 & Specific Conductance & N/A & $<250$ & YES & N/A & EPA-120.1 & conductivity mete \\
\hline 1 & 1 & Temperature & N/A & $<250$ & YES & N/A & EPA-170.1 & thermometer \\
\hline 1 & 2 & rinsate/discard & N/A & N/A & YES & N/A & N/A & N/A \\
\hline 2 & 1 & Metals & Plastic & $\frac{100}{100}$ & YES & HNO3 (<2pH) & EPA-6010 & ICP \\
\hline 2 & 1 & Anions ( $\left.\mathrm{Br}^{*}, \mathrm{Cl}, \mathrm{Fl}, \mathrm{NO}, \mathrm{SO} 4\right)$ & Plastic & 100 & YES & NONE & EPA-300.0 & IC \\
\hline 2 & 2 & Alkalinity & Plastic & 100 & YES & NONE & EPA-310.1 & titration \\
\hline 3 & 1 & VOC & Amber/Glass & $40 \times 2$ & $\mathrm{NO}$ & NONE & OLMO1.8 & GC/MS \\
\hline
\end{tabular}

Low Permeability**

\begin{tabular}{|c|c|c|c|c|c|c|c|c|}
\hline $\begin{array}{r}\text { Sar } \\
\text { Run No. }\end{array}$ & $\begin{array}{l}\text { mple } \\
\text { Bottle No. }\end{array}$ & Parameter & $\begin{array}{c}\text { Container } \\
\text { Type }\end{array}$ & $\begin{array}{c}\begin{array}{c}\text { Volume } \\
\text { (ml) }\end{array} \\
\end{array}$ & Filtered & Preservative & $\begin{array}{c}\text { EPA } \\
\text { Procedure No. }\end{array}$ & $\begin{array}{l}\text { Analytical } \\
\text { Method }\end{array}$ \\
\hline 1 & 1 & Alkalinity & Plastic & $50-100$ & YES & NONE & $\begin{array}{c}\text { done in field OR } \\
\text { EPA-310.1 }\end{array}$ & $\begin{array}{l}\text { titration } \\
\text { titration }\end{array}$ \\
\hline 1 & 1 & Anions $\left(\mathrm{Br}^{*}, \mathrm{Cl}, \mathrm{Fl}, \mathrm{NO} 3, \mathrm{SO} 4\right)$ & Plastic & 100 & YES & NONE & EPA-300.0 & ICP \\
\hline 1 & 2 & $\mathrm{pH}$ & N/A & $<250$ & YES & N/A & EPA-150.1 & $\mathrm{pH}$ meter \\
\hline 1 & 2 & Specific Conductance & N/A & $<250$ & YES & N/A & EPA-120.1 & conductivity meter \\
\hline 1 & 2 & Temperature & N/A & $<250$ & YES & N/A & EPA-170.1 & thermometer \\
\hline 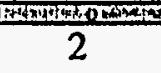 & $\frac{1}{1}$ & 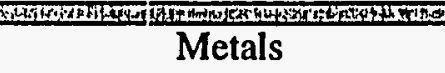 & 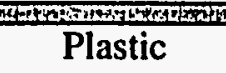 & $\frac{100}{100}$ & YES & HNO3 $(<2 \mathrm{pH})$ & EPA-6010 & ICP \\
\hline 2 & 2 & VOC & Amber/Glass & $40 \times 2$ & NO & NONE & OLMO1.8 & GC/MS \\
\hline \multicolumn{9}{|c|}{$\begin{array}{l}\text { * Br analysis is requested if specific conductance is greater than } 2000 \mathrm{umho} / \mathrm{cm} \\
* * \text { Nitrogen gas used to aid sampling. } \\
\text {-All samples cooled to } 4 \text { degrees celsius unless otherwise noted }\end{array}$} \\
\hline
\end{tabular}


A common occurance with sampling low permeability zones is that the O-ring seal is compromised around the measurement port. This can be determined by monitoring the water level in the MP casing. A drop in water level is attributed to water from the MP casing that moves past the O-rings, through the sample probe, and into the sample bottles. The resultant sample is a mixture of water from the annular space and from the MP casing. If this happens, the zone is treated as a "low permeability zone" and both the sampling order and collection method is modified (Table 4). Field parameters will be collected from the first run second (lower) bottle. This bottle will have the least amount of rinsing with formation waters. Alkalinity and anions will be collected from the first run first (upper) bottle. The remainder of the sample will be collected from the second run. As before, VOCs will not be sampled from the first run to assure that the sample bottle is rinsed with formation water. If a O-ring seal is broken during sampling, water collected from the first run, second bottle will be used to re-rinse the bottle.

In low-permeability zones, the seal around the measurement port may be broken because: (1) the zone could not produce enough water to maintain a sufficient fluid pressure; and (2) there is a large pressure differential between the sample bottles, the MP casing water and the formation water. The purpose of the modified sampling collection procedure is to reduce the pressure differential between the sample bottles and the pressure in the MP casing. This is accomplished by pressurizing the sample bottles with inert nitrogen gas between 50 and $110 \mathrm{psi}$. This pressure is well below the fluid pressure in the MP casing and the formation, yet is sufficient enough to maintain the integrity of the seal around the measurement port valve allowing water to be drawn from the formation. To date, this method has been successful when used in low permeability zones.

The sampling history for GW-730 is given in Table 5. Zones that show the low permeability characteristics mentioned above include zones 30 and below. Of these nine zones, seven did not produce the requisite purge water volumes in four weeks of purging (Table 3), which is another indication of low permeability. 
Table 5. GW-730 sampling history.

\begin{tabular}{|c|c|c|c|}
\hline Zone & Date & Parameters & Comments \\
\hline 2 & $3 / 15 / 95$ & $\begin{array}{c}\text { VOC } \\
\text { Metals, Anions, Alk. } \\
\text { field parameters }\end{array}$ & $\begin{array}{l}\text { Bromide included with Anions } \\
\text { used nitrogen gas } \\
\text { no separate rinsate run } \\
\text { 1st run void }\end{array}$ \\
\hline 7 & $3 / 15 / 95$ & $\begin{array}{l}\text { VOC } \\
\text { Metals, Anions, Alk. } \\
\text { field parameters }\end{array}$ & $\begin{array}{l}\text { Bromide included with Anions } \\
\text { used nitrogen gas } \\
\text { no separate rinsate run }\end{array}$ \\
\hline 11 & $3 / 15 / 95$ & $\begin{array}{l}\text { VOC } \\
\text { Metals, Anions, Alk. } \\
\text { field parameters }\end{array}$ & $\begin{array}{l}\text { used nitrogen gas } \\
\text { no separate rinsate run }\end{array}$ \\
\hline 15 & $3 / 23 / 95$ & $\begin{array}{l}\text { VOC } \\
\text { Metals, Anions, Alk. } \\
\text { field parameters }\end{array}$ & $\begin{array}{l}\text { Bromide included with Anions } \\
\text { used nitrogen gas } \\
\text { no separate rinsate run }\end{array}$ \\
\hline 18 & $11 / 3 / 94$ & $\begin{array}{l}\text { VOC } \\
\text { Metals, Anions, Alk. } \\
\text { field parameters }\end{array}$ & $\begin{array}{l}\text { Bromide included with Anions } \\
\text { used nitrogen gas } \\
\text { no separate rinsate run }\end{array}$ \\
\hline 21 & $11 / 2 / 94$ & $\begin{array}{l}\text { VOC } \\
\text { Metals, Anions, Alk. } \\
\text { field parameters }\end{array}$ & $\begin{array}{l}\text { Bromide included with Anions } \\
\text { used nitrogen gas } \\
\text { no separate rinsate run }\end{array}$ \\
\hline 25 & $11 / 2 / 94$ & $\begin{array}{l}\text { VOC } \\
\text { Metals, Anions, Alk. } \\
\text { field parameters }\end{array}$ & $\begin{array}{l}\text { Bromide included with Anions } \\
\text { used nitrogen gas } \\
\text { no separate rinsate run }\end{array}$ \\
\hline 28 & $10 / 26 / 94$ & $\begin{array}{l}\text { VOC } \\
\text { Metals, Anions, Alk. } \\
\text { field parameters }\end{array}$ & $\begin{array}{l}\text { used nitrogen gas } \\
1 \text { st run voided }\end{array}$ \\
\hline 30 & $10 / 26 / 94$ & $\begin{array}{c}\text { VOC } \\
\text { Metals, Anions, Alk. } \\
\text { field parameters }\end{array}$ & \\
\hline 35 & $9 / 22 / 94$ & $\begin{array}{l}\text { VOC } \\
\text { Metals, Anions, Alk. } \\
\text { field parameters }\end{array}$ & \\
\hline 39 & $9 / 22 / 94$ & $\begin{array}{c}\text { VOC } \\
\text { Metals, Anions, Alk. } \\
\text { field parameters }\end{array}$ & \\
\hline
\end{tabular}




\subsection{ANALYTICAL RESULTS}

\subsection{VOLATILE ORGANIC COMPOUNDS}

A sample was collected for VOC analysis for each zone (Table 5). Trip blanks were collected on 9/22/94, 10/26/94,11/2/94,3/16/95 and 3/23/95 and their results are listed in Appendix A. VOCs were detected three times in the trip blanks (Appendix A); two for methylene chloride (9/22/94 and 3/23/95) and one for 2-Butanone (9/22/94). The methylene chloride detects had " $\mathrm{J"}$ qualifiers showing that the levels were estimated were estimated at values that are below the detection limit, and the 3/27/95 detect had a "B" qualifier, showing that methylene chloride was also detected with a similar concentration in the lab blank. Laboratory blank data are given in Appendix B and show detects with "J" qualifiers of 2-Hexanone and Acetone for the 9/27/94 sample and Toluene for the 10/31/94 sample, as well as the previously mentioned methylene chloride detect.

VOC results from the sample zones are presented in Appendix $C$ and a list of 22 VOCs detects is given in Table 6. Most detectable values are flagged with a "J" qualifier and represent low $(1.0-10.0 \mu \mathrm{g} / \mathrm{L})$ but discernible responses from the analytical instrumentation. Of the $22 \mathrm{VOC}$ detects, 8 corresponded to the lab or trip blanks associated with the sample. The remaining detects with "J" qualifiers include one for methylene chloride (a common laboratory reagent) in zone 35, carbon disulfide in zones 18 and 39; and benzene is observed in all of the zones below and including zone 30. Based on results from GW-727 (Dreier and Caldanaro, in prep.), and GW-790 (Dreier and Caldanaro, in prep.), benzene appears to be a common detect in the low-permeability, deeper portions of the DNAPL monitoring wells. It is possible the pervasive presence of benzene in trace amounts is due to the occurance of natural hydrocarbons. However, benzene is a VOC is concern because it does occur in more than $5 \%$ of wells associated with the Y-12 Burial Grounds (HSW, 1994). In contrast to results from GW-T26 (Dreier and Caldanaro, 1995), none of the detects are for VOCs of concern that are known to be present in the DNAPL pool or immediate dissolved-phase plume that was encountered in GW-625 (e.g. PCE, TCE, 1,1,1-TCA, ethyltoluene and 2-Butanone) (Haase and King, 1990a). 
Table 6. GW-730 VOC analytical results that are tagged with a "J" qualifier.

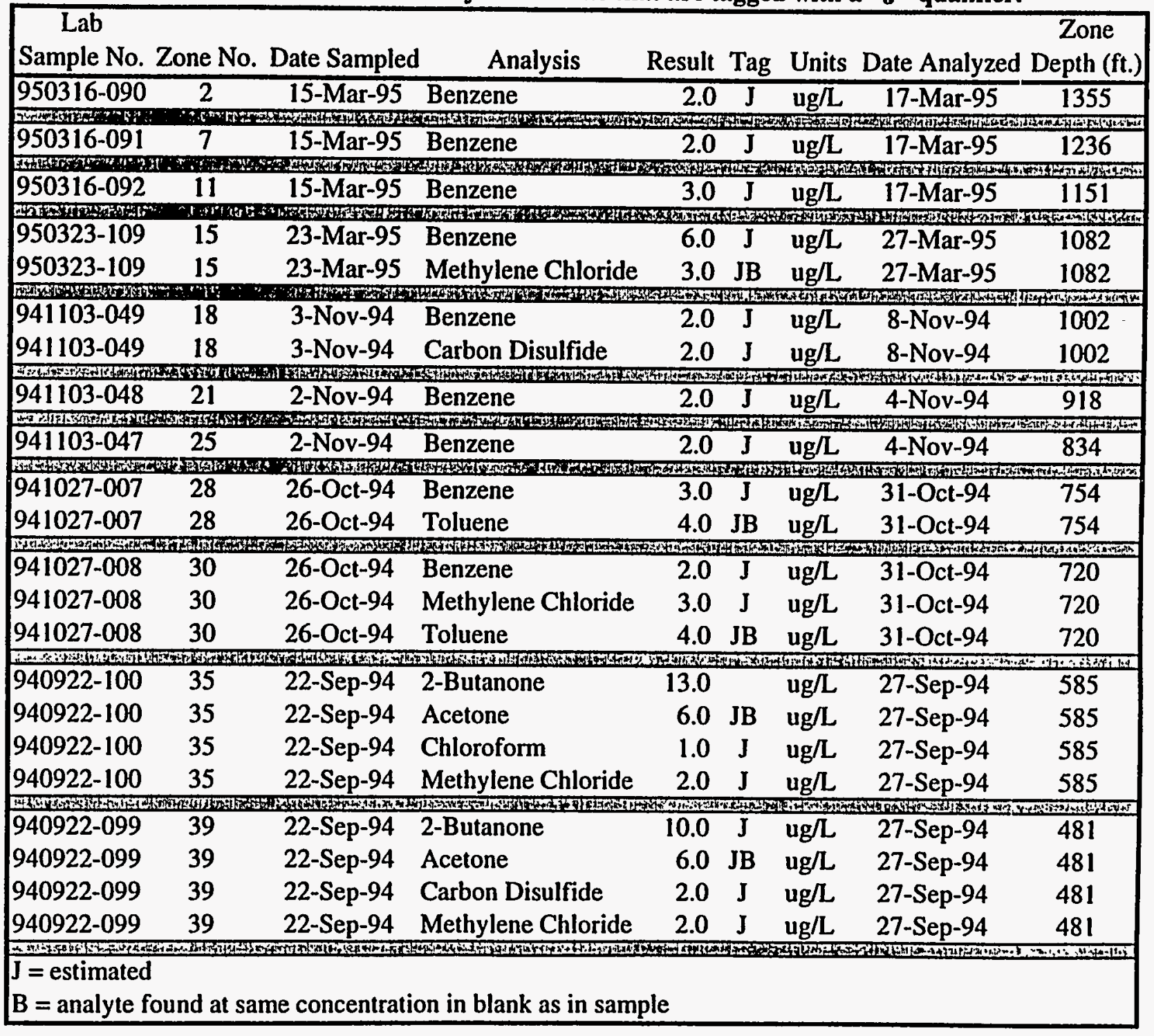




\subsection{TRACE METALS}

One sample per zone was collected for metal analysis (Table 5). Metal concentrations were determined by ICP spectroscopy and are listed in Appendix D. Available background screening levels listed in the GWQAR for Bear Creek Valley (HSW, 1994) are also listed in Appendix D, and detection limits are given as less than $(<)$ values in Appendix D. Samples from zones 28 and below were diluted because of high ionic concentrations. All of these zones showed TDS values greater than $6000 \mathrm{mg} / \mathrm{L}$ and dilution rates vary as a function of TDS: Zone 28 (TDS $=6346 \mathrm{mg} / \mathrm{L}$ ) had the least dilution with a dilution factor of 5 , and zone 7 (TDS $=176000 \mathrm{mg} / \mathrm{L}$ ) had the greatest dilution with a dilution factor of 200. As a result of the dilutions, detection limits are raised and some are raised above the background screening levels. This is the case for antimony, beryllium, cadmium, cobalt, lead, molybdenum, thorium, and vanadium (see Appendix D). Note also in Appendix D that the undiluted sample detection limits listed for antimony, lead, and thorium are equivalent to the background screening level for that constituent. Nevertheless, except for molybdenum, all analytical results for constituents with background screening levels below detection limits are below the detection limit, even though concentrations are expected to rise with an increase in TDS (TDS values are listed in Appendix E).

Boron, molybdenum, zinc, iron, manganese and strontium are above background screening levels for selected zones. The upper two zones in GW-730 (35 and 39) show boron levels above the background screening levels listed in the GWQAR for Bear Creek Valley (HSW, 1994). Boron values noticeably decrease with increase in depth and corresponding increase in TDS. The upper three zones $(30,35$ and 39$)$ show molybdenum values above the background screening level, and the remaining lower zones have a detection limit for molybdenum that is above the background screening level. Except for zone 11, all the zones below a depth of $740 \mathrm{ft}$ at the base of the borehole show elevated values of zinc that are above the background screening level of $0.079 \mathrm{mg} / \mathrm{L}$. Iron and manganese values are above background screening levels for zones 7,21 and 25. These three zones showed the highest TDS values in the borehole (all TDS values are above $60,000 \mathrm{mg} / \mathrm{L})$. 
Strontium also shows concentrations above the background screening level. The elevated concentrations occur in the deepest 9 zones (zones 2, 7, 11, 15, 18, 21, 25, 28 and 30) where there is also a corresponding increase in TDS. These zones show TDS values greater than $6300 \mathrm{mg} / \mathrm{L}$. The increase in strontium is apparently related to the increase in TDS as is suggested by the proportional correspondence between calcium and strontium concentrations (Fig. 4). Strontium will commonly substitute for calcium because they have the same valence state and a similar ionic radius.

\subsection{MAJOR ELEMENT W'ATER CHEMISTRY}

Major element water chemistry and field parameters are given in Appendix $E$ and charge balance information is given in Appendix F. Of immediate note is the potential presence of nitrate in zones 7 and 11 . However, it is important to realize that ion chromatography, the analytical technique used for anion analysis, may give misleading results for high chloride waters, which is the type of water that most of the zones in GW-730 produce. Zones 7 and 11 will be resampled specifically for nitrate analysis, and an analytical technique will be used where there is no interference between chloride and nitrate peaks. Similarly, there is a potential problem with the bromide results because of chloride interference. Although the specific conductance of zones 11,20 and 28 are above 2000 umho/cm, $\mathrm{Br}$ was not collected for analysis for these zones; for zone 11 it was an oversight, and zones 20 and 28 were sampled before the bromide procedure was initiated.

In general, ionic concentrations are given with two significant digits. Note, however, that for chloride, the significant digits range from two to five. At present, the reason for this change has not been determined and is being investigated with the K-25 Analytical Laboratory. Nine of the eleven zones showed a charge balance that is less than $10 \%$. The other two zones, zones 7 and 18 , had balances of $-20 \%$ and $16 \%$ respectively.

Watei chemistry types are shown in Fig. 5. There is a systematic change in water type with depth from a relatively shallow $\mathrm{Na}-\mathrm{HCO}_{3}$ type water to a deep $\mathrm{Na}-\mathrm{Cl}$ type water. The upper two zones (zones 35 and 39 which show a depth range of $450-600 \mathrm{ft}$ ) are a $\mathrm{Na}$ $\mathrm{HCO}_{3}$ type water. The lowest nine zones (zones $30,28,25,21,18,15,11,7$, and 2 which show a depth range of $700-1370 \mathrm{ft}$ ) are a $\mathrm{Na}-\mathrm{Cl}$ type water. The change in water type with depth also roughly corresponds to an increase in TDS with depth (Fig. 5), although TDS values within the $\mathrm{Na}-\mathrm{Cl}$ type water vary considerably and are not directly related to increasing depth. There may be some correlation between the presence of fractures and high TDS values but this requires further evaluation of the multiport data together. 

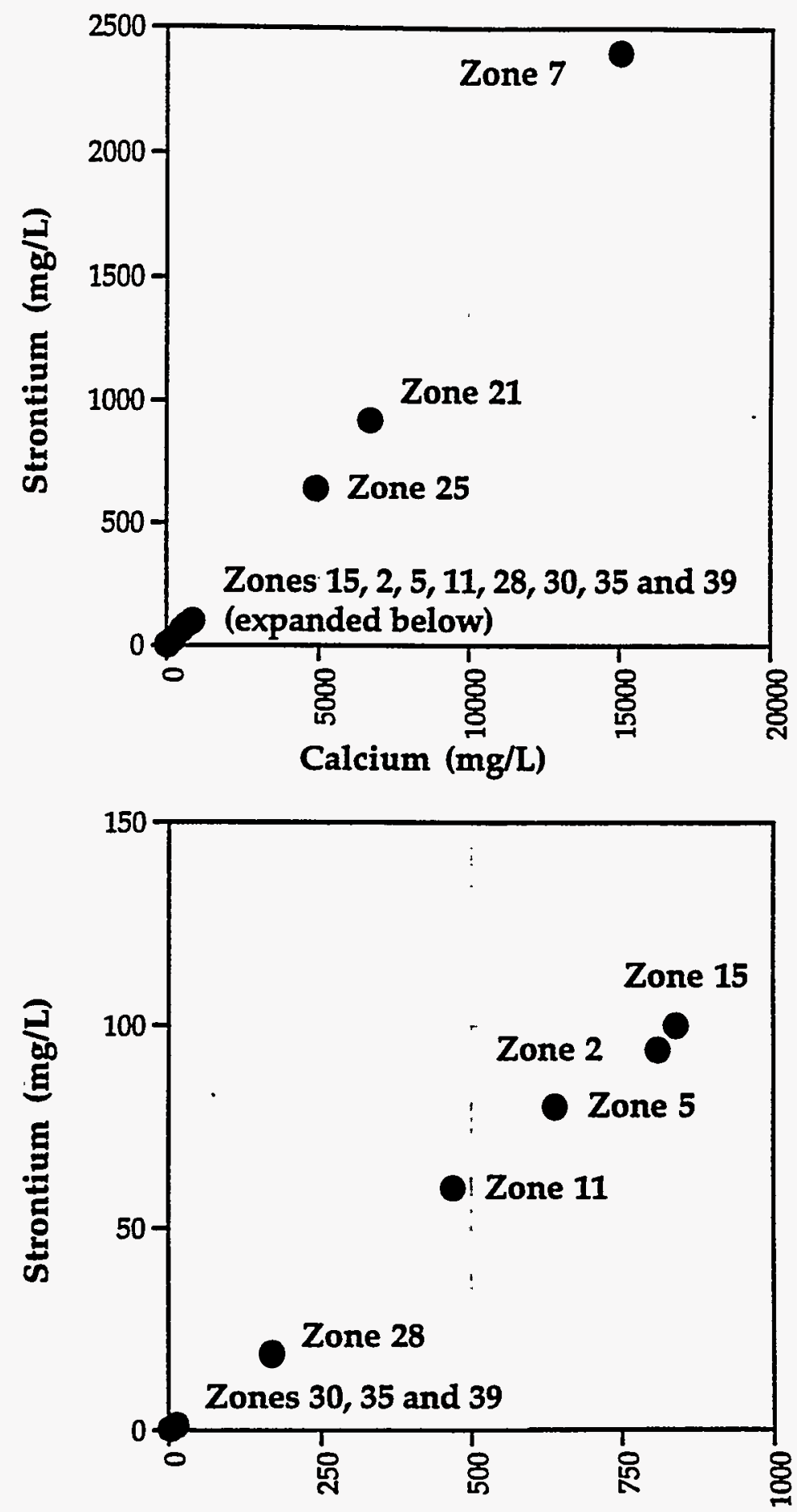

Calcium (mg/L)

Figure 4. Plot of strontium vs. calcium concentrations from GW-730. 


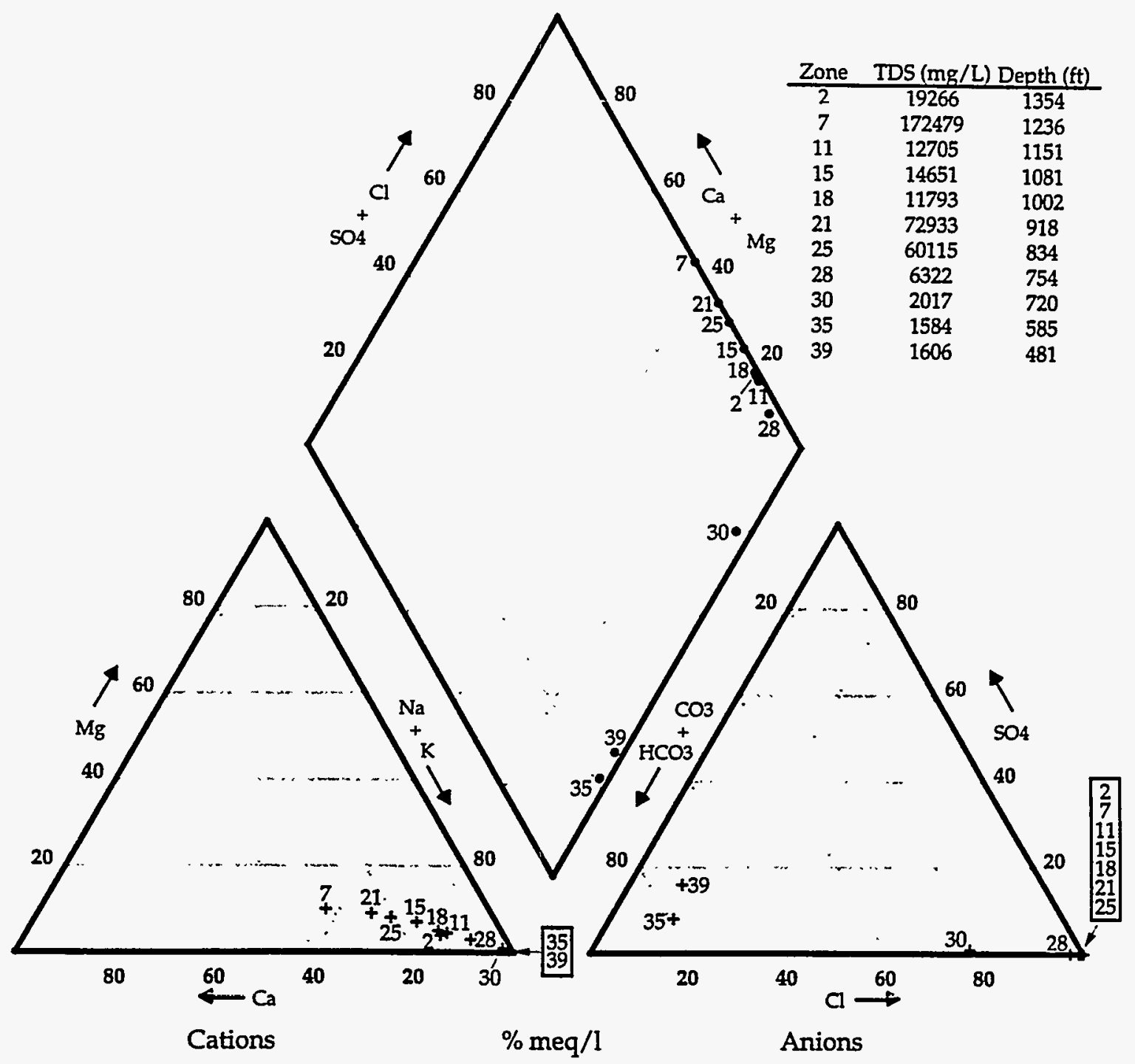

Figure 5. Piper diagram of GW-730 water chemistry. It should be noted that zones 7 and 18 were plotted for comparison purposes only. Both had charge balances greater than $\pm 10 \%$ ( -20 and +16 respectively). 


\subsection{SUMMARY / FUTURE WORK}

Ongoing and future tasks are directed toward collecting data that will provide information about: (1) the presence or absence of DNAPL or dissolved phase DNAPL and (2) the nature of the groundwater system so that the potential mobility of the dissolved phase plume can be evaluated. With this information we will be prepared to address concerns about the current extent of the contamination, the potential for continued spread of the contamination, and the need, if any, for implementing a remediation strategy.

To date, each of the eleven sampling zones in GW-730 has been sampled for VOCs, metals and anions. Based on the presence of very low levels of benzene at and below the base of the middle Nolichucky Shale, it is recommended that VOC monitoring of GW-730 be continued. Additional data is required in order to statistically confirm the presence or absence of VOCs through the use of "J" qualifiers. Zones 7 and 11 will be resampled in order to confirm or disprove the presence of nitrate in the deeper portions of the borehole. Purging activities will continue for zones $2,7,11,15$, and 18 to be followed by a second round of sampling. A comparison of the two sets of sampling results will be used to determine the need for a third round of purging. Any additional sampling from zones at the top of the well will be conducted without further purging, unless there is corroborative evidence that the water sample is not representative of the formation. There is a concern that excessive or unnecessary purging of units with low storativity, such as those in GW730 , will mobilize and extend the contaminant plume. 


\section{REFERENCES}

Dreier, R. B, and A. J. Caldanaro, 1994. Installation Summary for the DNAPL Characterization Multiport Wells, GW-726, GW-727, GW-729, GW-730 and GW-790. Y/ER-117.

Dreier, R. B, and A. J. Caldanaro, 1995, Sampling Results, DNAPL Monitoring Well GW-726, 2nd and 3rd Quarter, FY94. Y/ER-201.

Dreier, R. B, and A. J. Caldanaro, in prep, Sampling Results, DNAPL Monitoring Well GW-727, 1st and 2nd Quarter, FY95. Y/ER-202.

Dreier, R. B, and A. J. Caldanaro, in prep, Sampling Results, DNAPL Monitoring Well GW-790, 1st through 3rd Quarter, FY95. Y/ER-204.

Haase, C. S, and H. L. King, 1990a. Report and preliminary assessment of the occurrence of dense, nonaqueous phase liquids in the Bear Creek Burial Grounds Hazardous Waste Disposal Unit at the Oak Ridge Y-12 Plant. Y/TS-629.

Haase, C. S, and H. L. King, 1990b. "Work Plan for the Preliminary Assessment and Characterization of Dense Nonaqueous-Phase Liquids in the Bear Creek Burial Grounds Hazardous Waste Disposal Unit at the Oak Ridge Y-12 Plant", Y/ER-16.

Hatcher, R. D, Jr., P. J. Lemiszki, R. B. Dreier, R. H. Ketelle, R. R. Lee, D. A. Lietzke, W. M. McMaster, J. L. Foreman, and S.-Y. Lee 1992. Status Report on the Geology of the Oak Ridge Reservation. ORNL/TM-12074. Oak Ridge National Laboratory, Oak Ridge Tennessee, 37831-6285.

HSW Environmental Consultants, Inc. 1994. Calendar Year 1993 Groundwater Quality Assessment for the Bear Creek Hydrogeologic Regime Y-12 Plant, Oak Ridge, Tennessee: 1993 Groundwater Quality Data interpretations and Proposed Program Modifications. Y/SUB/94-EA1/1/P2.

Kueper, R. H. 1990. The occurrence of dense, nonaqueous phase liquids in fractured rock at the Bear Creek Burial Grounds Waste Management Area. Consultant Report submitted to Oak Ridge National Laboratory/Martin Marietta Energy Systems, Inc., on February 23, 1990.

Science Applications International Corporation 1993. Y-12 Environmental Restoration Dense Non-Aqueous Phase Liquid Investigation Field Report: GW-730. Y/ER102.

Westbay Instruments Inc., 1993. Completion report, DNAPL Investigation MP System Wells GW-726, 727, 729, 730 and 790. Consultant Report WB630-93. 
Appendix A

TRIP BLANK VOC ANALYTICAL RESULTS. 
Trip Blank VOC Analytical Results.

\begin{tabular}{|c|c|c|c|c|c|}
\hline $\begin{array}{l}\text { Trip Date: } \\
\text { Date Analyzed: } \\
\text { Units: }\end{array}$ & $\begin{array}{c}940922-101 \\
9 / 22 / 94 \\
9 / 27 / 94 \\
\mu \mathrm{g} / \mathrm{L}\end{array}$ & $\begin{array}{c}941027-009 \\
10 / 26 / 94 \\
11 / 1 / 94 \\
\mu \mathrm{g} / \mathrm{L}\end{array}$ & $\begin{array}{c}941103-050 \\
11 / 2 / 94 \\
11 / 8 / 94 \\
\mu \mathrm{g} / \mathrm{L}\end{array}$ & $\begin{array}{c}950316-106 \\
3 / 16 / 95 \\
3 / 17 / 95 \\
\mu g / \mathrm{L}\end{array}$ & $\begin{array}{c}950323-110 \\
3 / 23 / 95 \\
3 / 27 / 95 \\
\mu \mathrm{g} / \mathrm{L}\end{array}$ \\
\hline $\begin{array}{l}\text { 1,1,1-Trichloroethane } \\
\text { 1,1,2,2-Tetrachloroethane } \\
\text { 1,1,2-Trichloroethane } \\
\text { 1,1-Dichloroethane } \\
\text { 1,1-Dichloroethene } \\
\text { 1,2-Dichloroethane } \\
\text { 1,2-Dichloroethene (total) } \\
\text { 1,2-Dichloropropane } \\
\text { 2-Butanone } \\
\text { 2-Hexanone } \\
\text { 4-Methyl-2-pentanone } \\
\text { Acetone } \\
\text { Benzene } \\
\text { Bromodichloromethane } \\
\text { Bromoform } \\
\text { Bromomethane } \\
\text { Carbon Disulfide } \\
\text { Carbon Tetrachloride } \\
\text { Chlorobenzene } \\
\text { Chloroethane } \\
\text { Chloroform } \\
\text { Chloromethane } \\
\text { Dibromochloromethane } \\
\text { Ethylbenzene } \\
\text { Methylene Chloride } \\
\text { Styrene } \\
\text { Tetrachloroethene } \\
\text { Toluene } \\
\text { Trichloroethene } \\
\text { Vinyl Acetate } \\
\text { Vinyl Chloride } \\
\text { Xylene (total) } \\
\text { cis-1,3-Dichloropropene } \\
\text { trans-1,3-Dichloropropene }\end{array}$ & $\begin{array}{l}<10.0 \\
<10.0 \\
<10.0 \\
<10.0 \\
<10.0 \\
<10.0 \\
<10.0 \\
<10.0 \\
\quad 11.0 \\
<10.0 \\
<10.0 \\
<10.0 \\
<10.0 \\
<10.0 \\
<10.0 \\
<10.0 \\
<10.0 \\
<10.0 \\
<10.0 \\
<10.0 \\
<10.0 \\
<10.0 \\
<10.0 \\
<10.0 \\
<1.0 \\
<10.0 \\
<10.0 \\
<10.0 \\
<10.0 \\
<10.0 \\
<10.0 \\
<10.0 \\
<10.0 \\
<10.0 \\
\end{array}$ & $\begin{array}{l}<10.0 \\
<10.0 \\
<10.0 \\
<10.0 \\
<10.0 \\
<10.0 \\
<10.0 \\
<10.0 \\
<10.0 \\
<10.0 \\
<10.0 \\
<10.0 \\
<10.0 \\
<10.0 \\
<10.0 \\
<10.0 \\
<10.0 \\
<10.0 \\
<10.0 \\
<10.0 \\
<10.0 \\
<10.0 \\
<10.0 \\
<10.0 \\
<10.0 \\
<10.0 \\
<10.0 \\
<10.0 \\
<10.0 \\
<10.0 \\
<10.0 \\
<10.0 \\
<10.0 \\
<10.0\end{array}$ & $\begin{array}{l}<10.0 \\
<10.0 \\
<10.0 \\
<10.0 \\
<10.0 \\
<10.0 \\
<10.0 \\
<10.0 \\
<10.0 \\
<10.0 \\
<10.0 \\
<10.0 \\
<10.0 \\
<10.0 \\
<10.0 \\
<10.0 \\
<10.0 \\
<10.0 \\
<10.0 \\
<10.0 \\
<10.0 \\
<10.0 \\
<10.0 \\
<10.0 \\
<10.0 \\
<10.0 \\
<10.0 \\
<10.0 \\
<10.0 \\
<10.0 \\
<10.0 \\
<10.0 \\
<10.0 \\
<10.0\end{array}$ & $\begin{array}{l}<10.0 \\
<10.0 \\
<10.0 \\
<10.0 \\
<10.0 \\
<10.0 \\
<10.0 \\
<10.0 \\
<10.0 \\
<10.0 \\
<10.0 \\
<10.0 \\
<10.0 \\
<10.0 \\
<10.0 \\
<10.0 \\
<10.0 \\
<10.0 \\
<10.0 \\
<10.0 \\
<10.0 \\
<10.0 \\
<10.0 \\
<10.0 \\
<10.0 \\
<10.0 \\
<10.0 \\
<10.0 \\
<10.0 \\
<10.0 \\
<10.0 \\
<10.0 \\
<10.0 \\
<10.0\end{array}$ & 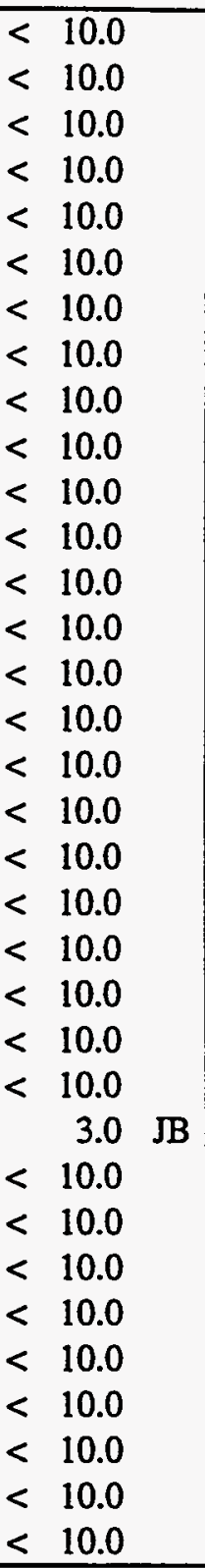 \\
\hline
\end{tabular}


Appendix B

LABORATORY BLANK VOC ANALYTICAL RESULTS. 
Laboratory Blank VOC Analytical Results.

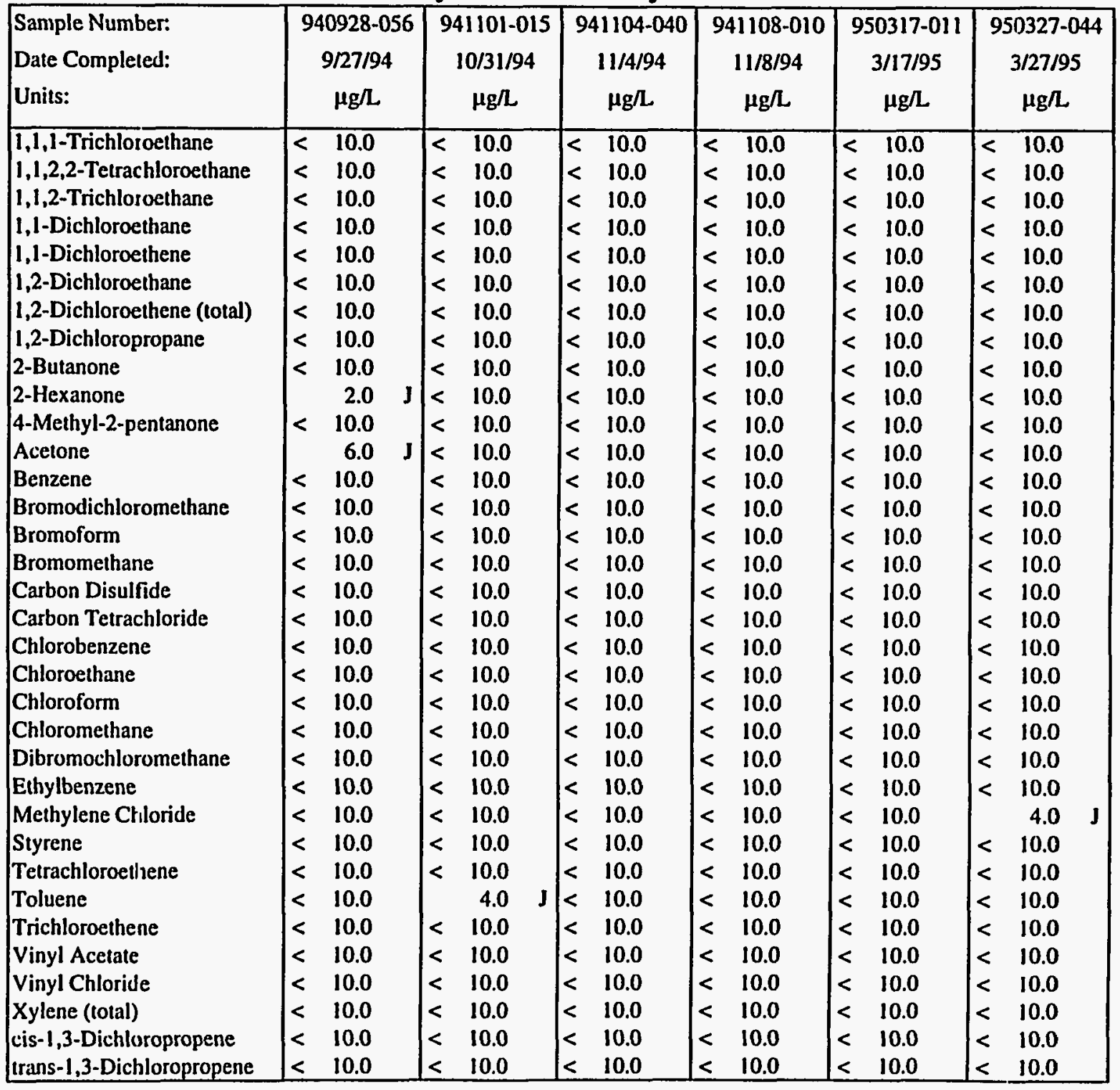


29

Appendix C

VOC ANALYTICAL RESULTS. 
VOC Analytical Results

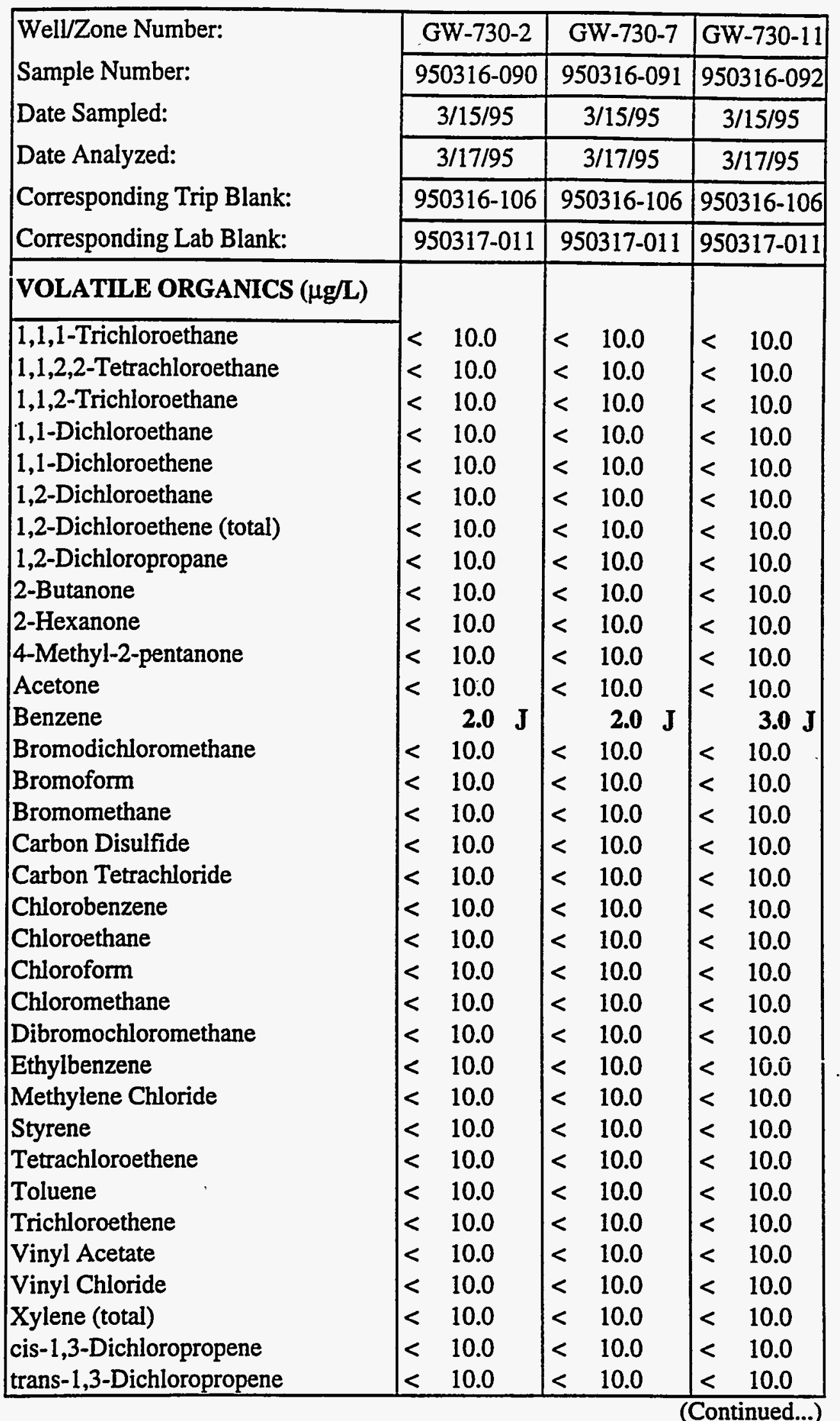


VOC Analytical Results

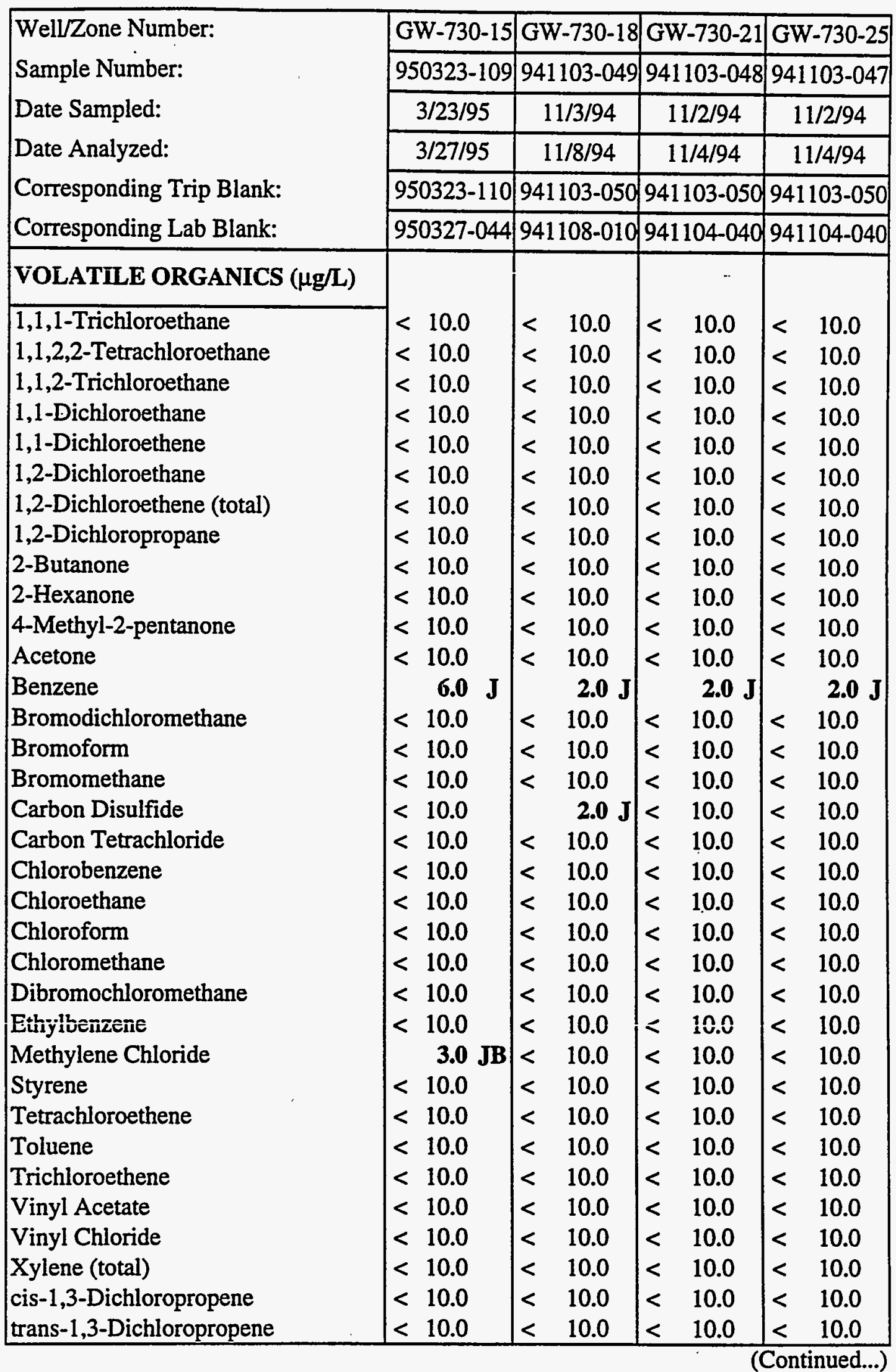


VOC Analytical Results

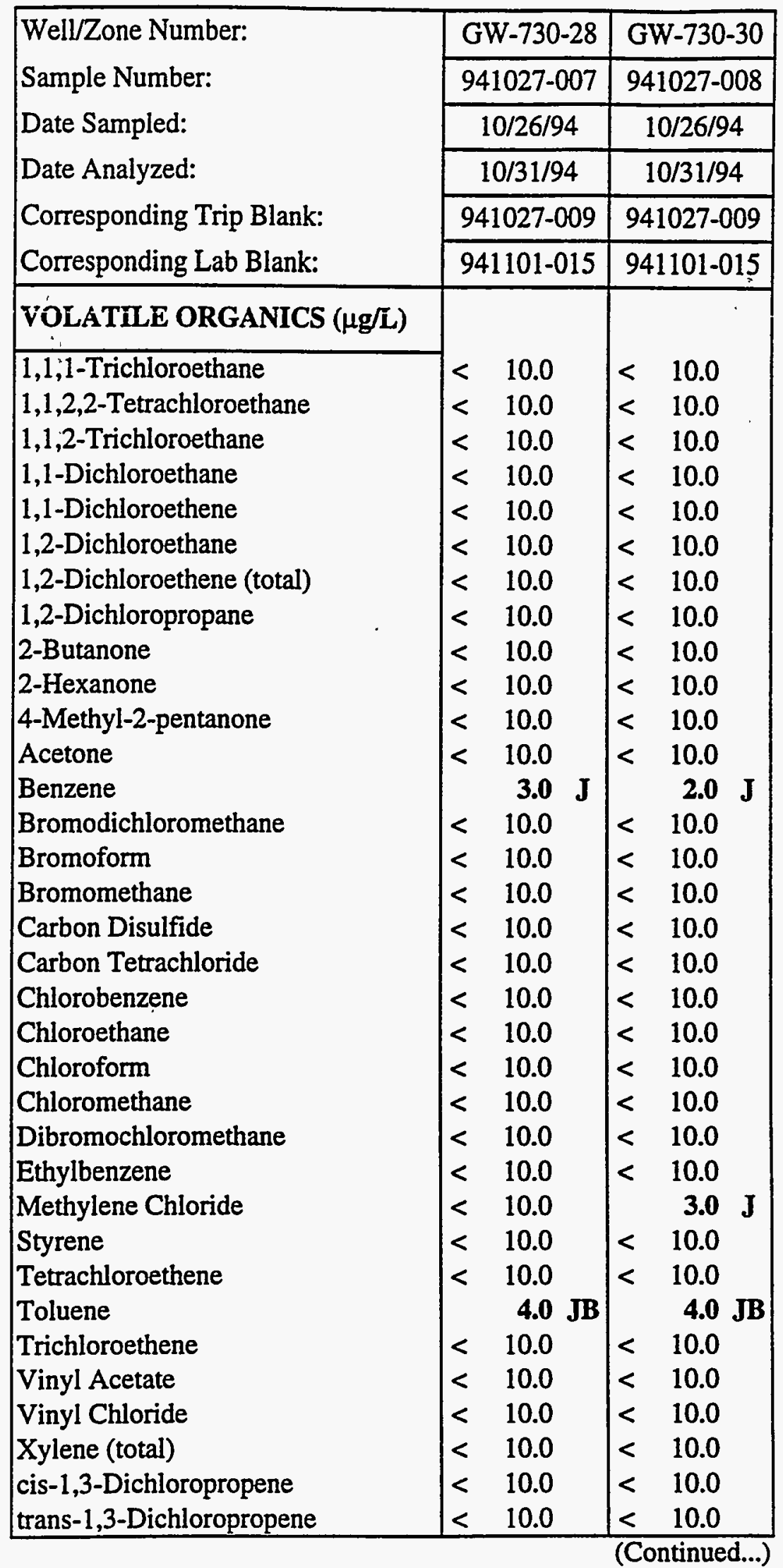


VOC Analytical Results

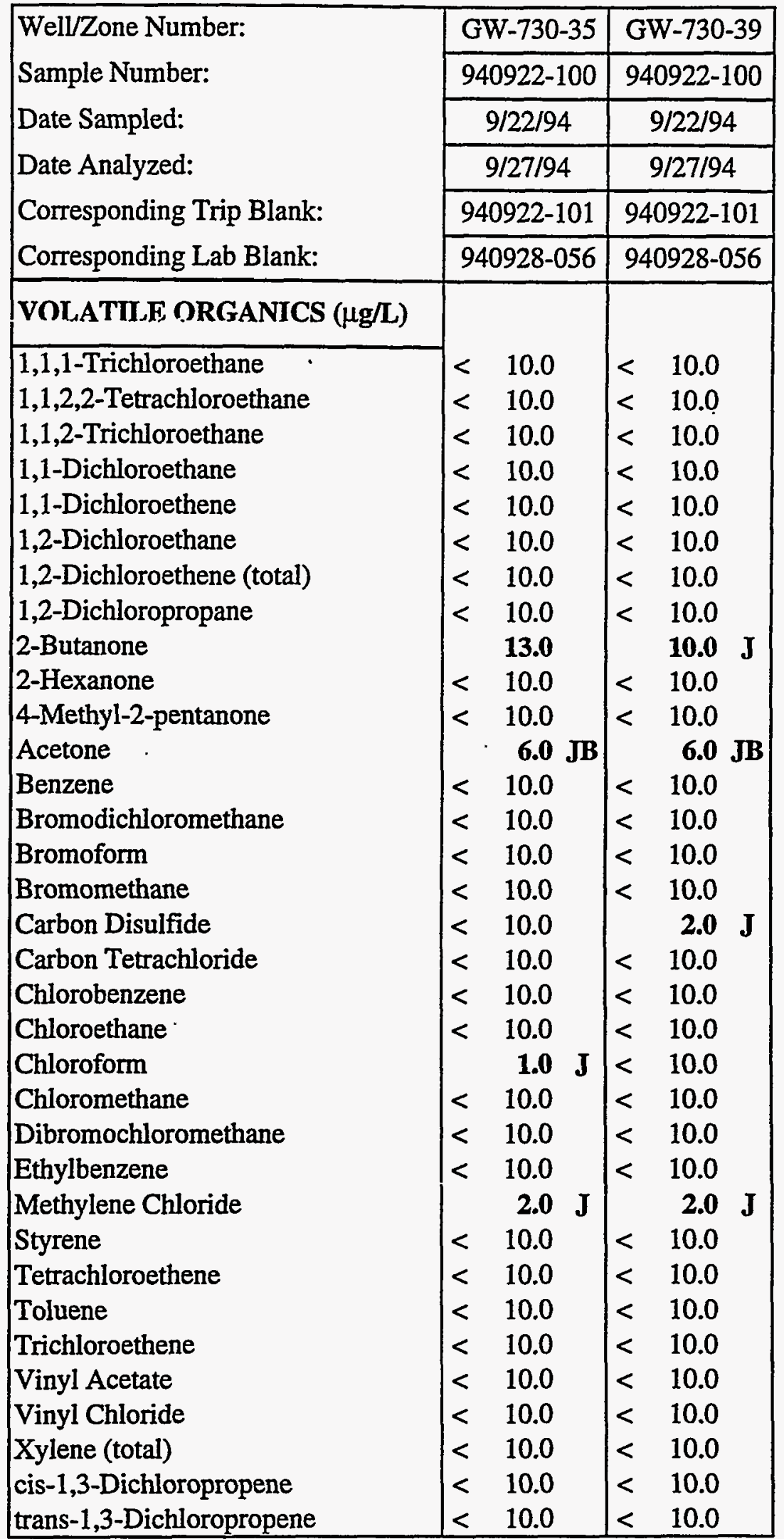


Appendix D

TRACE METAL ANALYTICAL RESULTS. 


\section{GW-730 Trace Metal Analytical Results}

\begin{tabular}{|c|c|c|c|c|c|c|c|c|c|c|c|c|c|}
\hline \multirow{2}{*}{$\begin{array}{l}\text { Well/Zone Number: } \\
\text { Date Sampled: }\end{array}$} & & \multicolumn{2}{|l|}{ GW-730-2 } & \multicolumn{2}{|l|}{ GW-730-7 } & \multicolumn{2}{|l|}{ GW-730-11 } & \multicolumn{2}{|l|}{ GW-730-15 } & \multicolumn{2}{|c|}{ GW-730-18 } & \multicolumn{2}{|c|}{ GW-730-21 } \\
\hline & & $3 / 15 / 95$ & & $3 / 15 / 95$ & & $3 / 15 / 95$ & & $3 / 23 / 95$ & & $1 / 3 / 94$ & & $11 / 2 / 94$ & \\
\hline METALS (mg/L) & $\begin{array}{c}\text { Background } \\
\text { Screening } \\
\text { levels* }\end{array}$ & & & & & & & & & & & & \\
\hline Aluminum & 7.9 & $<0.2$ & d & 4.0 & d & $<0.2$ & d & 0.22 & & $<0.2$ & $\mathrm{~d}$ & 3.0 & \\
\hline Antimony & 0.05 & $<0.5$ & d) & 10.0 & d & $<0.5$ & d & $<0.5$ & d] & $<0.5$ & d) & 5.0 & \\
\hline Arsenic & & $<0.5$ & d & $<\quad 10.0$ & d & $<0.5$ & d & $<0.5$ & d & 0.52 & & $<\quad 5.0$ & d \\
\hline Barium & & 39.0 & & 1100.0 & & 20.0 & & 42.0 & & 20.0 & & 280.0 & \\
\hline Beryllium & 0.0019 & $<0.003$ & d & $<\quad 0.06$ & d) & $<0.003$ & d & $<0.003$ & d] & $<0.003$ & d & 0.03 & d \\
\hline Boron & 0.57 & 0.16 & & 0.8 & d & 0.17 & & 0.14 & & 0.16 & & 0.53 & \\
\hline Cadmium & 0.005 & $<0.03$ & d & 0.6 & d & $<0.03$ & d & 0.03 & d & $<0.03$ & d & 0.3 & \\
\hline Chromium & & $<0.1$ & d & 2.0 & d & $<0.1$ & d & 0.1 & d & $<0.1$ & d) & 1.0 & d \\
\hline Cobalt & 0.025 & $<0.05$ & d & 1.0 & d & $<0.05$ & d & $<0.05$ & d & $<0.05$ & d & 0.5 & \\
\hline Copper & 0.3 & $<0.04$ & d & 0.8 & d & $<0.04$ & d & $<\quad 0.04$ & d & $<0.04$ & d & 0.4 & d \\
\hline Iron & 13.0 & 6.5 & & $\mathbf{5 2 . 0}$ & & 4.2 & & 2.0 & & 5.0 & & 46.0 & \\
\hline Lead & 0.05 & $<0.5$ & d) & 10.0 & d & $<0.5$ & d & 0.5 & d & $<0.5$ & d & 5.0 & \\
\hline Manganese & 2.7 & 1.5 & & 19.0 & & 0.39 & & 0.85 & & 0.47 & & 5.2 & \\
\hline Molybdenum & 0.01 & $<0.1$ & d) & 2.0 & d) & $<0.1$ & d & $<0.1$ & d) & $<0.1$ & d & 1.0 & \\
\hline Nickel & 0.33 & $<0.1$ & d & 2.0 & d & $<0.1$ & d & $<0.1$ & d & 0.32 & & 1.0 & \\
\hline Selenium & & 0.5 & d & 10.0 & d & 0.5 & d & 0.5 & d) & 0.5 & d & 5.0 & d \\
\hline Silver & & $<0.06$ & d & $<\quad 1.2$ & d & $<0.06$ & d & $<0.06$ & d & $<0.06$ & d & 0.6 & d \\
\hline Strontium & 0.83 & 94.0 & & 2400.0 & & 60.0 & & 100.0 & & 80.0 & & 920.0 & \\
\hline Thorium & 0.2 & $<2.0$ & d) & $<40.0$ & d] & $<2.0$ & d & $<2.0$ & d & $<2.0$ & d & 20.0 & \\
\hline Vanadium & 0.058 & $<\quad 0.05$ & d & 1.0 & d & $<0.05$ & d & 0.05 & d & $<0.05$ & d & 0.5 & \\
\hline Zinc & $0.0 \div 9$ & 0.23 & & 1.3 & & 0.05 & & 0.76 & & 0.2 & & 1.1 & \\
\hline Dilution factor & & 10 & & 200 & & 10 & & 10 & & 10 & & 100 & \\
\hline
\end{tabular}

* Background screening levels obtairied from HSW Environmental Consultants, 1994. Levels listed are for ORR Aquitards. Where blank, there is no screening level listed.

** italicized values show a detection limit that is above the recommended background screening level.

*** bold face values show levels that are above the detection limit and the background screening level. 
GW-730 Trace Metal Analytical Results

\begin{tabular}{|c|c|c|c|c|c|c|c|}
\hline Well/Zone Number: & & GW-730-25 & & GW-730-28 & GW-730-30 & GW-730-35i & GW-730-39 \\
\hline Date Sampled: & & $11 / 2 / 94$ & & $10 / 26 / 94$ & $10 / 26 / 94$ & $9 / 22 / 94$ & $9 / 22 / 94$ \\
\hline METALS (mg/L) & \begin{tabular}{|c|}
$\begin{array}{c}\text { Background } \\
\text { Screening } \\
\text { levels* }\end{array}$ \\
\end{tabular} & & & & & & \\
\hline Aluminum & 7.9 & $<\quad 2.0$ & d) & $<0.1$ & 0.025 & $<0.02$ & 0.037 \\
\hline Antimony & 0.05 & $<5.0$ & d) & $<0.25$ & $<0.05$ & $<0.05$ & $<0.05$ \\
\hline Arsenic & & $<\quad 5.0$ & d) & 0.28 & 0.088 & $<0.05$ & $<0.05$ \\
\hline Barium & & 190.0 & & 4.4 & 0.31 & 0.084 & 0.05 \\
\hline Beryllium & 0.0019 & 0.03 & d) & $0.0015 \mathrm{~d}$ & $<0.0003$ & $<0.0003$ & $<0.0003$ \\
\hline Boron & 0.57 & 0.4 & d) & 0.32 & 0.42 & 1.2 & 1.7 \\
\hline Cadmium & 0.005 & 0.3 & d) & $0.0015 \mathrm{~d}$ & $<0.003$ & $<0.003$ & $<0.003$ \\
\hline Chromium & & 1.0 & d) & $0.05 \mathrm{~d}$ & $<0.01$ & $<0.01$ & $<0.01$ \\
\hline Cobalt & 0.025 & $<0.5$ & d) & 0.025 & $<0.005$ & $<0.005$ & $<0.005$ \\
\hline Copper & 0.3 & 0.4 & d) & 0.02 & $<0.004$ & $<0.004$ & $<0.004$ \\
\hline Iron & 13.0 & 41.0 & & 0.9 & 0.0092 & 0.034 & 0.026 \\
\hline Lead & 0.05 & 5.0 & d) & $<0.25$ & $<0.05$ & $<0.05$ & $<0.05$ \\
\hline Manganese & 2.7 & 3.4 & & 0.11 & 0.01 & 0.0021 & 0.0028 \\
\hline Molybdenum & 0.01 & $<\quad 1.0$ & d) & $<0.05$ & 0.024 & 0.021 & 0.017 \\
\hline Nickel & 0.33 & $<\quad 1.0$ & d) & $<0.05$ & $<0.01$ & $<0.01$ & $<0.01$ \\
\hline Selenium & & 5.0 & d & 0.25 & $<0.05$ & $<0.05$ & $<0.05$ \\
\hline Silver & & $<\quad 0.6$ & d) & $<\quad 0.03$ & $<0.006$ & $<0.006$ & $<0.006$ \\
\hline Strontium & 0.83 & 640.0 & & 19.0 & 1.2 & 0.29 & 0.31 \\
\hline Thorium & 0.2 & $<20.0$ & d) & $<1.0$ & $<0.2$ & $<0.2$ & $<0.2$ \\
\hline Vanadium & 0.058 & $<\quad 0.5$ & d) & $<0.025$ & $<0.005$ & $<0.005$ & $<0.005$ \\
\hline Zinc & 0.079 & 1.3 & & 0.14 & 0.011 & 0.016 & 0.021 \\
\hline \multicolumn{2}{|l|}{ Dilution factor } & 100 & & 5 & 1 & 1 & 1 \\
\hline
\end{tabular}

* Background screening levels obtained from HSW Environmental Consultants, 1994. Levels listed are for ORR Aquitards. Where blank, there is no screening level listed.

** italicized values show a detection limit that is above the recommended background screening level.

*** bold face values show levels that are above the detection limit and the background screening level. 
Appendix E

MAJOR ANIONS AND CATIONS AND FIELD PARAMETERS. 
Major Anions and Cations and Field Parameters.

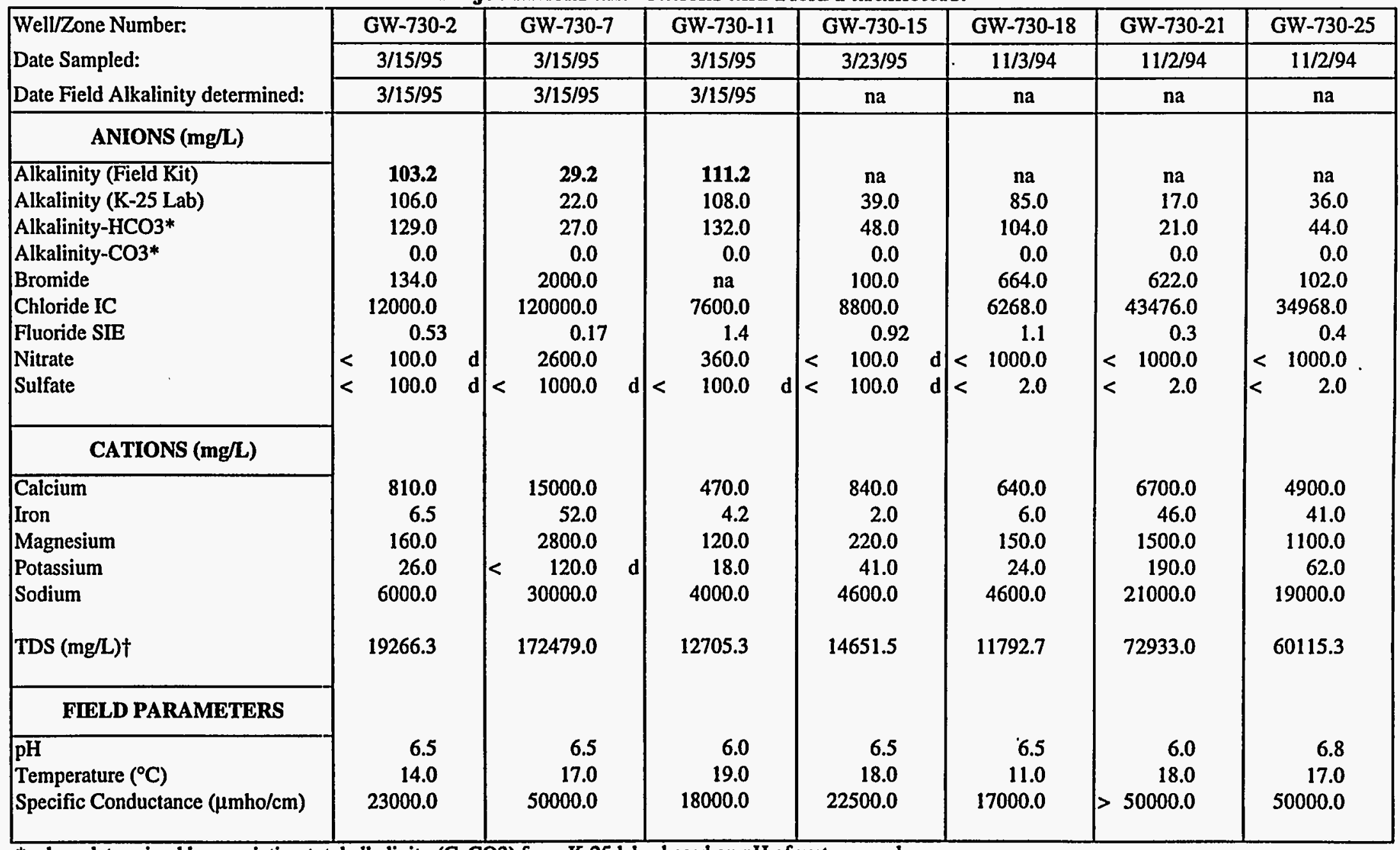

*values determined by speciating total alkalinity (CaCO3) from $\mathrm{K}-25$ labs, based on $\mathrm{pH}$ of water sample.

Bolded alkalinity values (zones 2,7 , and 11) denote use of a field alkalinity test kit. These values are used for comparison purposes only.

† Sum of major anions and cations $(\mathrm{mg} / \mathrm{L})$.

$\mathrm{d}=$ indicates sample diluted for analysis.

na $=$ not analyzed 
Major Anions and Cations and Field Parameters.

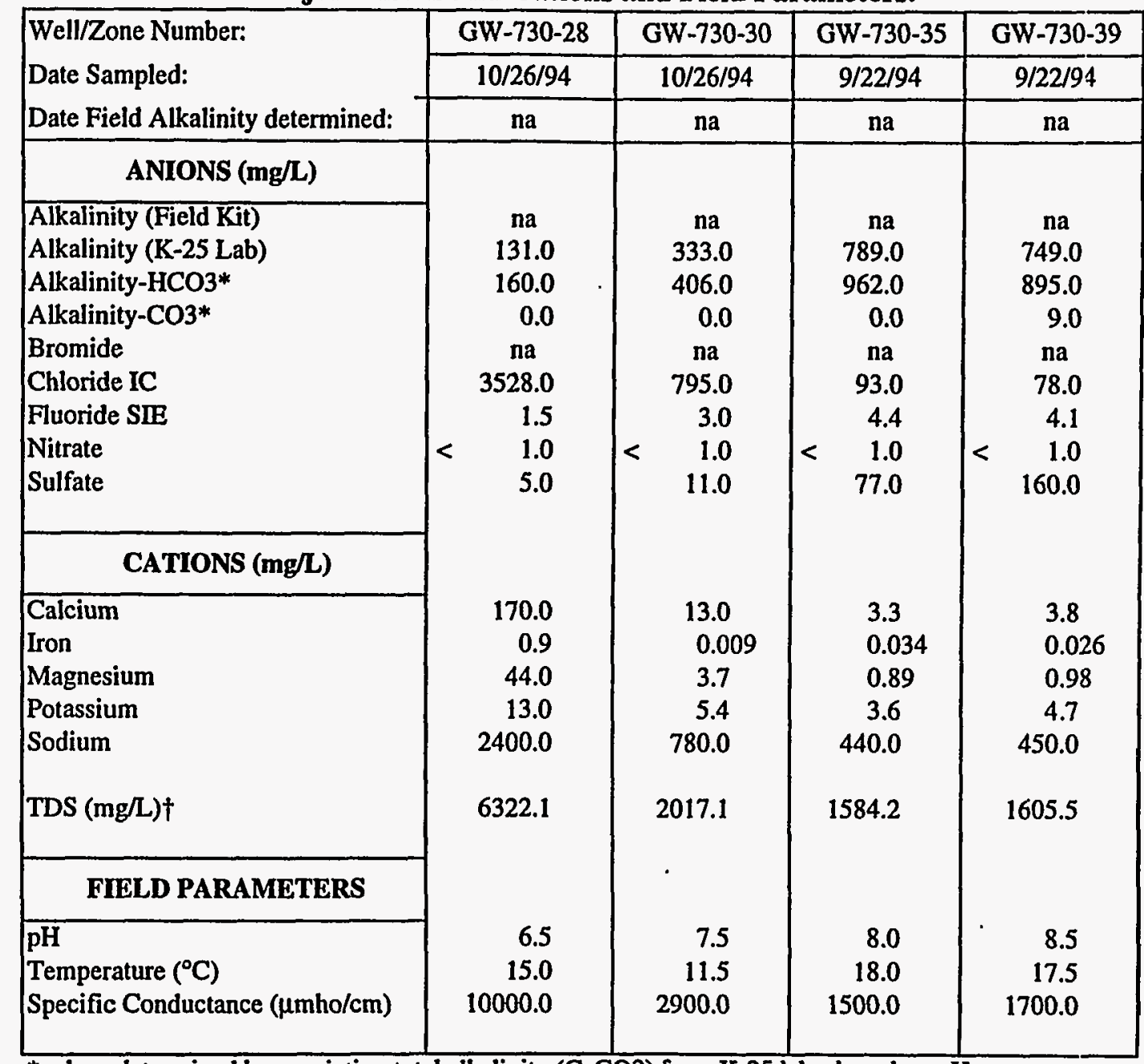

*values determined by speciating total alkalinity (CaCO3) from $\mathrm{K}-25$ labs, based on $\mathrm{pH}$ of water sample.

tSum of major anions and cations (mg/L).

$\mathrm{d}=$ indicates sample diluted for analysis.

na $=$ not analyzed 
Appendix F CHARGE BALANCE CALCULATIONS. 
Charge Balance Calculations

\begin{tabular}{|c|c|c|c|c|c|c|}
\hline Well/Zone Number: & GW-730-2 & GW-730-7 & GW-730-11 & GW-730-15 & GW-730-18 & GW-730-21 \\
\hline Date Sampled: & $3 / 15 / 95$ & $3 / 15 / 95$ & $3 / 15 / 95$ & $3 / 23 / 95$ & $11 / 3 / 94$ & $11 / 2 / 94$ \\
\hline \multicolumn{7}{|l|}{ ANIONS (meq/L) } \\
\hline Alkalinity-HCO3 & 2.1 & 0.4 & 2.2 & 0.8 & 1.7 & 0.3 \\
\hline Alkalinity-CO3 & 0.0 & 0.0 & 0.0 & 0.0 & 0.0 & 0.0 \\
\hline Bromide & 1.7 & 25.0 & 0.0 & 1.3 & 0.0 & 0.0 \\
\hline Chloride IC & 338.4 & 3384.4 & 214.3 & 248.2 & 176.8 & 1226.2 \\
\hline Fluoride SIE & 0.0 & 0.0 & 0.1 & 0.0 & 0.1 & 0.0 \\
\hline Nitrate & 0.0 & 41.9 & 5.8 & 0.0 & 0.0 & 0.0 \\
\hline Sulfate IC & 0.0 & 0.0 & 0.0 & 0.0 & 0.0 & 0.0 \\
\hline Total Anions & 342.3 & 3451.8 & 222.4 & 250.3 & 178.5 & 1226.5 \\
\hline \multicolumn{7}{|l|}{ CATIONS (meq/L) } \\
\hline Calcium & 40.4 & 748.5 & 23.5 & 41.9 & 31.9 & 334.3 \\
\hline Iron & 0.3 & 2.8 & 0.2 & 0.1 & 0.3 & 2.5 \\
\hline Magnesium & 13.2 & 230.3 & 9.9 & 18.1 & 12.3 & 123.4 \\
\hline Potassium & 0.7 & 0.0 & 0.5 & 1.0 & 0.6 & 4.9 \\
\hline Sodium & 260.9 & 1304.5 & 173.9 & 200.0 & 200.0 & 913.2 \\
\hline Total Cations & 315.5 & 2286.1 & 207.9 & 261.2 & 245.2 & 1378.2 \\
\hline CHARGE BALANCE (\%) & -4 & -20 & -3 & 2 & 16 & 6 \\
\hline
\end{tabular}


Charge Balance Calculations

\begin{tabular}{|c|c|c|c|c|c|}
\hline Well/Zone Number: & GW-730-25 & GW-730-28 & GW-730-30 & GW-730-3 & GW-730-39 \\
\hline Date Sampled: & $11 / 2 / 94$ & $10 / 26 / 94$ & $10 / 26 / 94$ & $9 / 22 / 94$ & $9 / 22 / 94$ \\
\hline ANIONS (meq/L) & & & & & \\
\hline Alkalinity-HCO3 & 0.7 & 2.6 & 6.7 & 15.8 & 14.7 \\
\hline Alkalinity-CO3 & 0.0 & 0.0 & 0.0 & 0.0 & 0.3 \\
\hline Bromide & 0.0 & 0.0 & 0.0 & 0.0 & 0.0 \\
\hline Chloride IC & 986.2 & 99.5 & 22.4 & 2.6 & 2.2 \\
\hline Fluoride SIE & 0.0 & 0.1 & 0.2 & 0.2 & 0.2 \\
\hline Nitrate & 0.0 & 0.0 & 0.0 & 0.0 & 0.0 \\
\hline Sulfate IC & 0.0 & 0.1 & 0.2 & 1.6 & 3.3 \\
\hline Total Anions & 986.9 & 102.3 & 29.5 & 20.2 & 20.7 \\
\hline CATIONS (meq/L) & & & & & \\
\hline Calcium & 244.5 & 8.5 & 0.6 & 0.2 & 0.2 \\
\hline Iron & 2.2 & 0.0 & 0.0 & 0.0 & 0.0 \\
\hline Magnesium & 90.5 & 3.6 & 0.3 & 0.1 & 0.1 \\
\hline Potassium & 1.6 & 0.3 & 0.1 & 0.1 & 0.1 \\
\hline Sodium & 826.2 & 104.4 & 33.9 & 19.1 & 19.6 \\
\hline Total Cations & 1165.0 & 116.8 & 35.0 & 19.5 & 20.0 \\
\hline CHARGE BALANCE (\%) & 8 & 7 & 9 & -2 & -2 \\
\hline
\end{tabular}




\section{DISTRIBUTION}

1. L. V. Asplund

2. A. J. Caldanaro

3-9. R. B. Dreier

10. T. O. Early

11. J. A. Hodgins

12. D. D. Huff

13. G. K. Jacobs

14. W. K. Jago

15. S. B. Jones

16. H. L. King

17-18. A. K. Lee/OSTI

19. D. M. Matteo

20. G. R. Moline

21. H. C. Newsom

22-23. P. T. Owen

24. E. Owens

25-29. C. T. Rightmire

30. S. H. Stowe

31. L. E. Toran

32. D. B. Watson

33. C. S. Walker

34-38. ER Document Management Center-RC

39. J. A. Archer, Jacobs Engineering, 125 Broadway, Oak Ridge, TN 37830

40. K. Black, EC Corporation, 10511 Hardin Valley Rd., Knoxville, TN 37932

41. P. Hofmann, DOE-ORO, P. O. Box 2001, Oak Ridge, TN 37831

42. B. H. Keuper, Queen's University Department of Engineering, Kingston, Ontario, Canada KJL 3 N6

43. L. A. Shevenell, Nevada Bureau of Mines and Geology, MS 178, Reno, NV 89557-0088

44. D. Moss, SAIC; 800 Oak Ridge Turnpike, P. O. Box 2502, Oak Ridge, TN 37831

45. J. Walker, HSW, 687 Emory Valley Rd., Suite B, Oak Ridge, TN 37830 